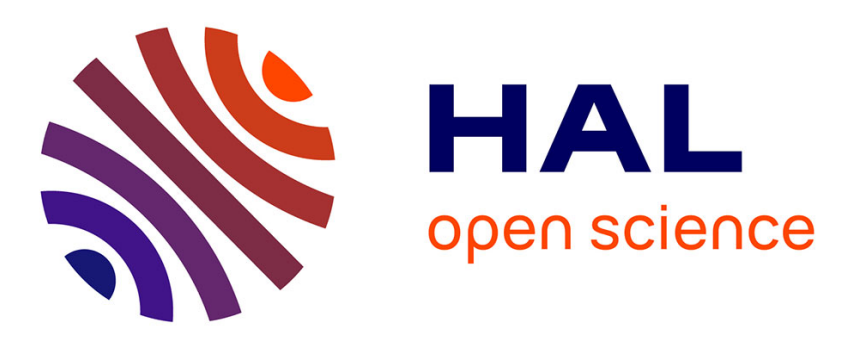

\title{
Introducing katabatic winds in global ERA40 fields to simulate their impacts on the Southern Ocean and sea-ice
}

Pierre Mathiot, Bernard Barnier, Hubert Gallée, Jean-Marc Molines, Julien Le Sommer, Mélanie Juza, Thierry Penduff

\section{To cite this version:}

Pierre Mathiot, Bernard Barnier, Hubert Gallée, Jean-Marc Molines, Julien Le Sommer, et al.. Introducing katabatic winds in global ERA40 fields to simulate their impacts on the Southern Ocean and sea-ice. Ocean Modelling, 2010, 35 (3), pp.146-160. 10.1016/j.ocemod.2010.07.001 . hal-00570152

\section{HAL Id: hal-00570152 \\ https://hal.science/hal-00570152}

Submitted on 13 Feb 2020

HAL is a multi-disciplinary open access archive for the deposit and dissemination of scientific research documents, whether they are published or not. The documents may come from teaching and research institutions in France or abroad, or from public or private research centers.
L'archive ouverte pluridisciplinaire HAL, est destinée au dépôt et à la diffusion de documents scientifiques de niveau recherche, publiés ou non, émanant des établissements d'enseignement et de recherche français ou étrangers, des laboratoires publics ou privés. 


\title{
Introducing katabatic winds in global ERA40 fields to simulate their impacts on the Southern Ocean and sea-ice
}

\author{
Pierre Mathiot ${ }^{\mathrm{a}, \mathrm{d}, *}$, Bernard Barnier ${ }^{\mathrm{a}}$, Hubert Gallée ${ }^{\mathrm{b}}$, Jean Marc Molines ${ }^{\mathrm{a}}$, Julien Le Sommer ${ }^{\mathrm{a}}$, \\ Mélanie Juza ${ }^{a}$, Thierry Penduff ${ }^{\mathrm{a}, \mathrm{c}}$ \\ ${ }^{a}$ LEGI UMR5519, CNRS, UJF, Grenoble, France \\ ${ }^{\mathrm{b}}$ LGGE UMR5183, CNRS, UJF, Grenoble, France \\ ${ }^{\mathrm{c}}$ FSU, Department of Oceanography, The Florida State University, Tallahassee, FL, United States \\ ${ }^{\mathrm{d}}$ TECLIM, Earth and Life Institute, Université Catholique de Louvain, Louvain la Neuve, Belgium
}

A medium resolution (10-20 km around Antarctica) global ocean/sea-ice model is used to evaluate the impact of katabatic winds on sea-ice and hydrography. A correction is developed to compensate for the drastic underestimation of these katabatic winds in the ERA40 reanalysis. This correction derives from a comparison over 1980-1989 between wind stress in ERA40 and those downscaled from ERA40 by the MAR regional atmospheric model. The representation in MAR of the continental orography surrounding the ocean, like the Transantarctic Mountains, and a specific parameterisation of roughness length in the planetary boundary layer yield a major improvement in the representation of katabatic winds along the coast of Antarctica. Wind stress directions at the first ocean point are remarkably similar in ERA40 and MAR, but MAR wind stress amplitudes are much greater. From this comparison, a scale factor constant in time (i.e. no seasonal variation) but spatially varying (decreasing off-shore over a distance of about $150 \mathrm{~km}$ ) is created for the meridional and zonal wind stress components and adapted to the wind vector. The correction thus consists of a local amplification of the amplitude of the 6-hourly ERA40 wind vector components at ocean points near the coast. The impact of katabatic wind correction is investigated in 40-year long twin simulations of a global ocean/sea-ice model. The wind stress over polynyas is increased by a factor of 2 , and amplitudes of sensible and latent air-sea heat exchanges are increased by $28 \%$ and $18 \%$, respectively. Sea-ice thickness and ice-fraction near the coast of Antarctica show a marked decrease. The amplified katabatic winds also increase the extent of coastal polynyas by $24 \%$ (i.e. the total polynya area is augmented by $60,000 \mathrm{~km}^{3}$ around Antarctica), and the winter sea-ice production in polynyas is greater by $42 \%$. Outside polynyas, the impact is a reduction of sea-ice production in the Southern Ocean sea-ice pack. Impacts on the ocean circulation are also marked. Katabatic wind amplification strengthens the local overturning in coastal polynyas with a more intense transformation of Antarctic Surface Waters into colder and denser shelf waters (in total over all polynyas around Antarctica, the overturning reaches $4.7 \mathrm{~Sv}$ in annual mean, an increase of $1.8 \mathrm{~Sv}$, and peaks to $6 \mathrm{~Sv}$ in winter). The modification of shelf water properties and of the zonal surface winds yields an increase of the amplitude of the seasonal cycle of the Antarctic Coastal Current.

\section{Introduction}

Antarctic katabatic winds are gravity winds generated by intense radiation cooling of air adjacent to ice sheet surfaces, especially in winter. Their strength is largely determined by local orography, which explains that they are rather persistent in

* Corresponding author. Address: Georges Lemaître Centre for Earth and Climate Research, Earth and Life Institute, Université Catholique de Louvain, 2 Chemin du Cyclotron, 1348 Louvain-la-Neuve, Belgium. Tel.: +32 10472676 .

E-mail address: pierre.mathiot@uclouvain.be (P. Mathiot). strength and direction, and why they are particularly strong in the presence of a topographic confluence.

As they get in contact with the ocean surface, these cold winds promote high rates of sea-ice formation as they continually push sea-ice away from the coast line, creating ice free areas (i.e. polynyas) in winter at selected locations along the Antarctica coast. The effect of katabatic winds can extend over $100 \mathrm{~km}$ off-shore (Adolphs and Wendler, 1995), although they typically lose most of their momentum within a few tens of kilometres from the coast (Bromwich and Kurtz, 1984).

According to Massom et al. (1998), katabatic winds are responsible for the formation of 16 polynyas of the 28 that have been 
observed along East Antarctica. Oceanic effects of these polynyas are an intense cooling of surface waters, and a brine rejection associated with the formation of new sea-ice. Ocean vertical mixing and convection are consequently increased, and dense waters formed on the shelf will later influence the properties of intermediate and deep waters around Antarctica. A description of katabatic winds and of the dynamics of polynyas may be found in Parish (1988) and Maqueda et al. (2004), respectively.

The small scale orography (e.g. glacier valleys crossing the Transantarctic Mountains) that largely influences katabatic winds is generally not well represented in global atmospheric general circulation models (AGCMs) that are used for global weather analyses or reanalyses (Van Den Broeke et al., 1997; Petrelli et al., 2008). The regional atmospheric models MAR (Modèle Atmosphérique Régional, Gallée and Schayes, 1994) has parameterisations dedicated to ice-air interactions, and a locally tuned orography roughness. These improved configurations help simulate more realistic katabatic winds, as shown by Petrelli et al. (2008). However, no reanalysis was produced with such models over the last 50 years, and their use in constructing an atmospheric forcing of a global ocean general circulation model (OGCM) relevant to the period 1960 to present requires dedicated downscaling and blending work. A way to do this, attempted by few authors in various manners (see Section 3), is to work out a correction of the reanalysed winds that improves the coastal effects of katabatic winds on the simulated sea-ice and ocean properties.

The ultimate objective of the present work is to study the impact of katabatic winds on sea-ice and ocean properties around Antarctica in a global ocean/sea-ice model. For that purpose, we first develop a correction to ERA40 winds in order to better account for the katabatic winds effects. The MAR model, forced laterally by the ERA40 reanalysis, was run over 10-years (1980-1989), and thus provided a regional downscaling of ERA40 over Antarctica with improved boundary layer dynamics. Comparing the outputs of the regional model with the reanalysis yields a local correction of the global ERA40 winds. The effects of katabatic winds on the ocean properties are then assessed by simulations carried out with a global model configuration of the NEMO OGCM (Madec, 2008), at a resolution of $1 / 2^{\circ}$.

Section 2 provides a short description of the characteristics of ERA40 and MAR models, along with a comparison between their surface fields. The description of the katabatic wind correction follows in Section 3. Section 4 presents the various NEMO based model configurations and the simulation strategy. The ocean model results are analysed in Section 5, sorting out the effects of katabatic winds on sea-ice and water masses.

\section{Near-coast atmospheric surface conditions in ERA40 and MAR}

To provide guidelines for the construction of the correction of ERA40 winds, we compare the wind stresses of the global reanalysis with those produced by the MAR atmospheric regional model. The comparison is focused on the wind stress component at the coast around Antarctica. This regional model, which has slightly finer horizontal and vertical resolutions, uses a bottom boundary layer adapted to ice-covered regions, and an orography calibrated for katabatic winds.

\subsection{The ERA40 reanalysis}

ERA40 is a global weather reanalysis covering the period 19582001 (Uppala et al., 2005). It provides the surface atmospheric fields that ocean general circulation models need as input for their surface boundary conditions, at a 6-hourly frequency on an equiv- alent grid of $125 \mathrm{~km}$ with a vertical resolution of $10 \mathrm{~m}$ at the surface. Van Den Broeke et al. (1997) showed that many characteristics of the Antarctic weather system (mid-latitude westerlies, near surface wind speed, etc.) were well simulated in reanalyses, but they also reported that the AGCM used at ECMWF in 1997 for the forecast was underestimating wind speeds in coastal areas, especially along the East coast of Antarctica. The study of Petrelli et al. (2008) reaches the same conclusion for ERA40 winds near Terra Nova Bay. This flaw in reanalyses was attributed to the sea-ice parameterisation and to the smoothing of the steep marginal ice slopes in the model orography. However, Petrelli et al. (2008) and Jourdain and Gallée (2010) show that the MAR regional atmospheric model, dedicated to Antarctic region, is able to produce realistic katabatic winds.

\subsection{The MAR model}

MAR is a mesoscale, primitive equation regional atmospheric model and is fully described in Gallée and Schayes (1994). It uses sigma (i.e. terrain following) coordinates to accurately represent surface conditions with complex topography. All terms of the continuity equation are included (i.e., the model is fully compressible). An $E-\varepsilon$ turbulence model (Duynkerke, 1988) parameterises vertical subgrid-scale fluxes as a function of local flow characteristics, as required by the complex structure of the katabatic layer (Gallée and Schayes, 1992). Four types of hydrometeors are taken into account in the cloud and precipitation schemes, with processes of auto-conversion and accretion. The lateral and top boundary conditions of the regional model are prescribed from the host model (i.e. ERA40). A nudging/diffusion zone of the MAR variables to host model variables is set up near the boundaries. The roughness length used in the boundary layer scheme is deduced from the spatial variance of orography (Jourdain and Galleee, 2010). This length was tuned with respect to the model resolution using observations from the Antarctic Automatic Weather Stations (AWS) to improve the representation of winds across the Transantarctic Mountains valleys. This tuning is a key point in order to get a good representation of katabatic winds (Jourdain and Gallée, 2010). For the present study, MAR is implemented in a domain that covers the Antarctic ice sheet and a part of the Southern Ocean from $60^{\circ} \mathrm{S}$ to the South Pole (see Fig. 1a). The grid is a cartesian grid on a polar stereographic projection. Horizontal resolution is $100 \mathrm{~km}$ (only a slight improvement compared to the $125 \mathrm{~km}$ of ERA40), but the vertical resolution is also increased within the planetary boundary layer, and is about $10 \mathrm{~m}$ for the first level.

\subsection{Downscaling of ERA40 by MAR}

The MAR regional model has been run for 10 years, from 1980 to 1989 , and calculated the atmospheric variables inside the $60^{\circ} \mathrm{S}$ circle shown in Fig. 1a, using ERA40 variables at the $60^{\circ} \mathrm{S}$ boundary. This simulation was done in a different context from the present study, and only the surface wind stress vector was saved. We do not have access to the other variables of the planetary boundary layer, such as the wind velocity vector, the air temperature and humidity, etc.

Before evaluating the differences between ERA40 and the MAR downscaling, we describe briefly the mean patterns of ERA40 wind stress around Antarctica. The meridional and zonal components of the ERA40 wind stress (1980-1989 mean) are shown in Fig. 1a and b. The main features that are of importance in the present study are the katabatic winds and the easterly winds. Katabatic winds appear as strong off-shore winds in coastal areas. Generally blowing off-shore right at the coast (red spots in Fig. 1a near-coastal stations 3, 2 and 9 for example), they are deflected to the left by the Coriolis force as they move over the ocean (or sea-ice), driving 

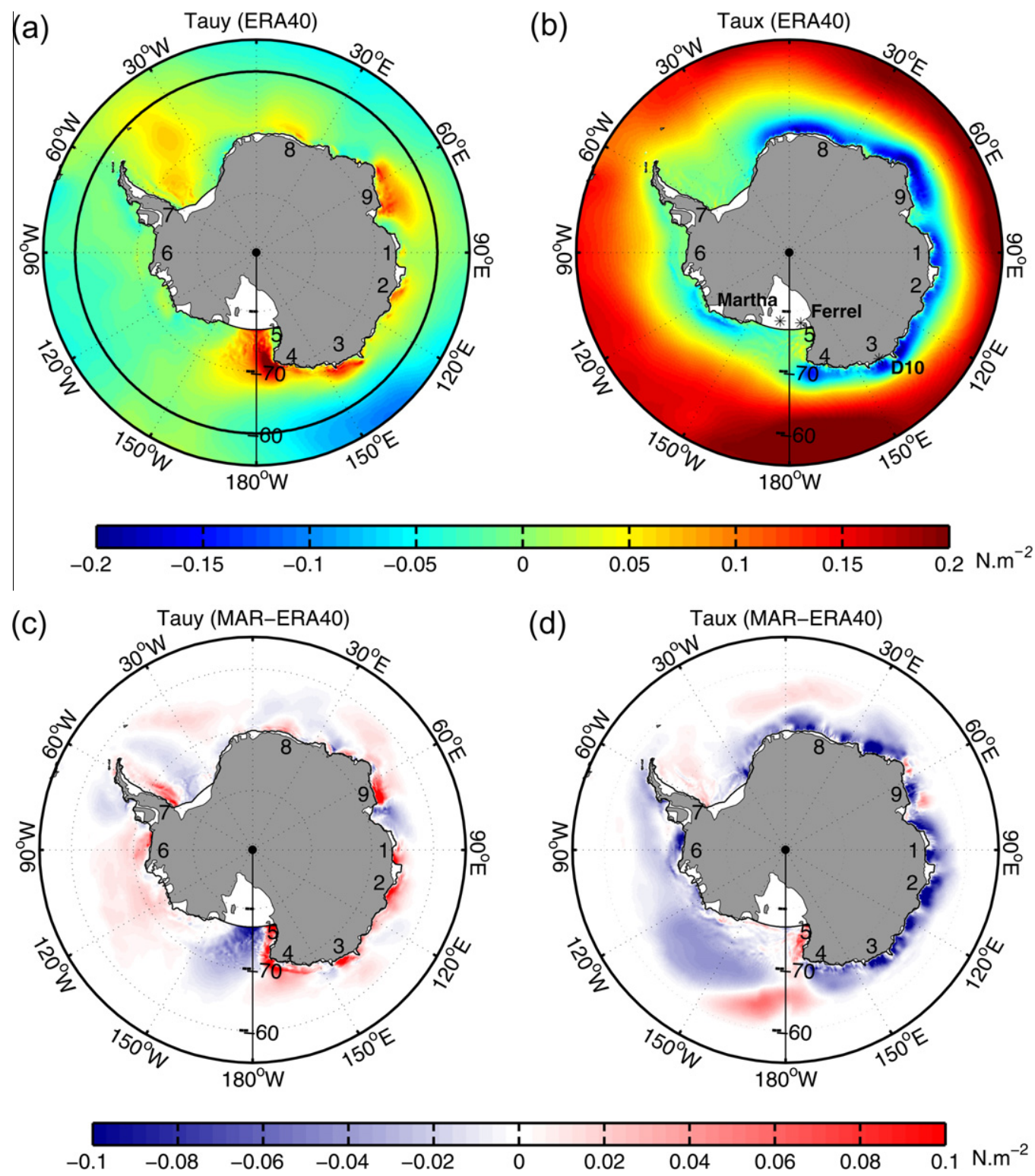

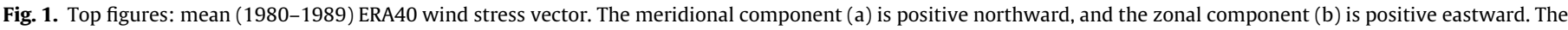

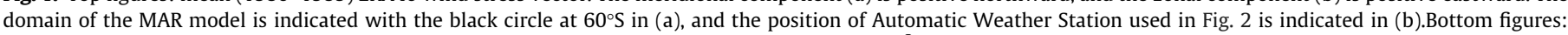

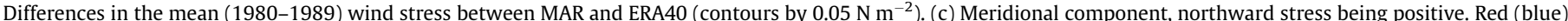

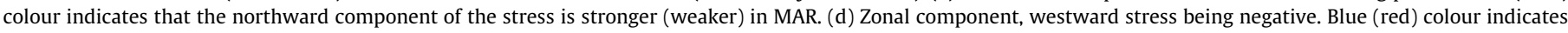

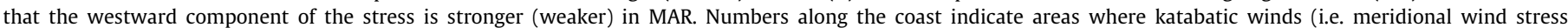

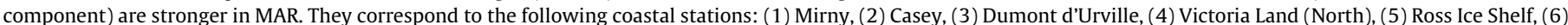

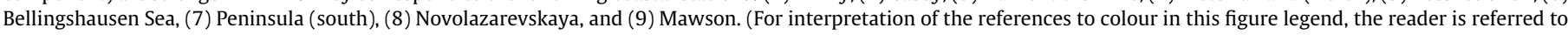
the web version of this article.)

strong easterlies (blue area in Fig. 1b near number 3, 2, 1, 9 and 8 for example) along the coast of Antarctica (Davis and Mc Nider, 1997).

Winds produced by the MAR downscaling are compared to direct observations at 3 near-coast locations (AWS D10, Ferrel and Martha, see their respective location in Fig. 1b). Such comparison is made difficult by the fact that AWS provide wind speed observations at $3 \mathrm{~m}$ height, whereas we only have the wind stress from MAR (calculated with a bulk formula using the $10 \mathrm{~m}$ wind). We proceeded as follows. The observed $3 \mathrm{~m}$ winds have been converted into $10 \mathrm{~m}$ winds by multiplication of a scale factor of 1.15 , as recommended by Van Den Broeke et al. (1997) for neutral conditions at the automatic weather stations. Then, MAR $10 \mathrm{~m}$ wind speed was estimated from the wind stress using the classical bulk formula for neutral conditions, with a drag coefficient of $\mathrm{CD}=1.4 \times 10^{-3}$, and the value of the air density corresponding to a temperature of $-10^{\circ} \mathrm{C}$. Fig. 2 compares this latter estimation of the MAR wind speed with observations at three different AWS (daily means time series for year 1986 at AWS D10 and for year 1989 at AWS Ferrel and Martha). Observations and MAR generally agree on the amplitude of the winds and its seasonal and intra seasonal variability. However, MAR slightly overestimates the wind speed during the periods of calm seen in the observations (especially at Ferrel and D10 station). Although limited and qualitative (partly because of the conversion from stress to wind), this comparison is consistent with the study of Jourdain and Gallée (2010) that concluded to realistic simulation of katabatic and barrier winds in MAR. 

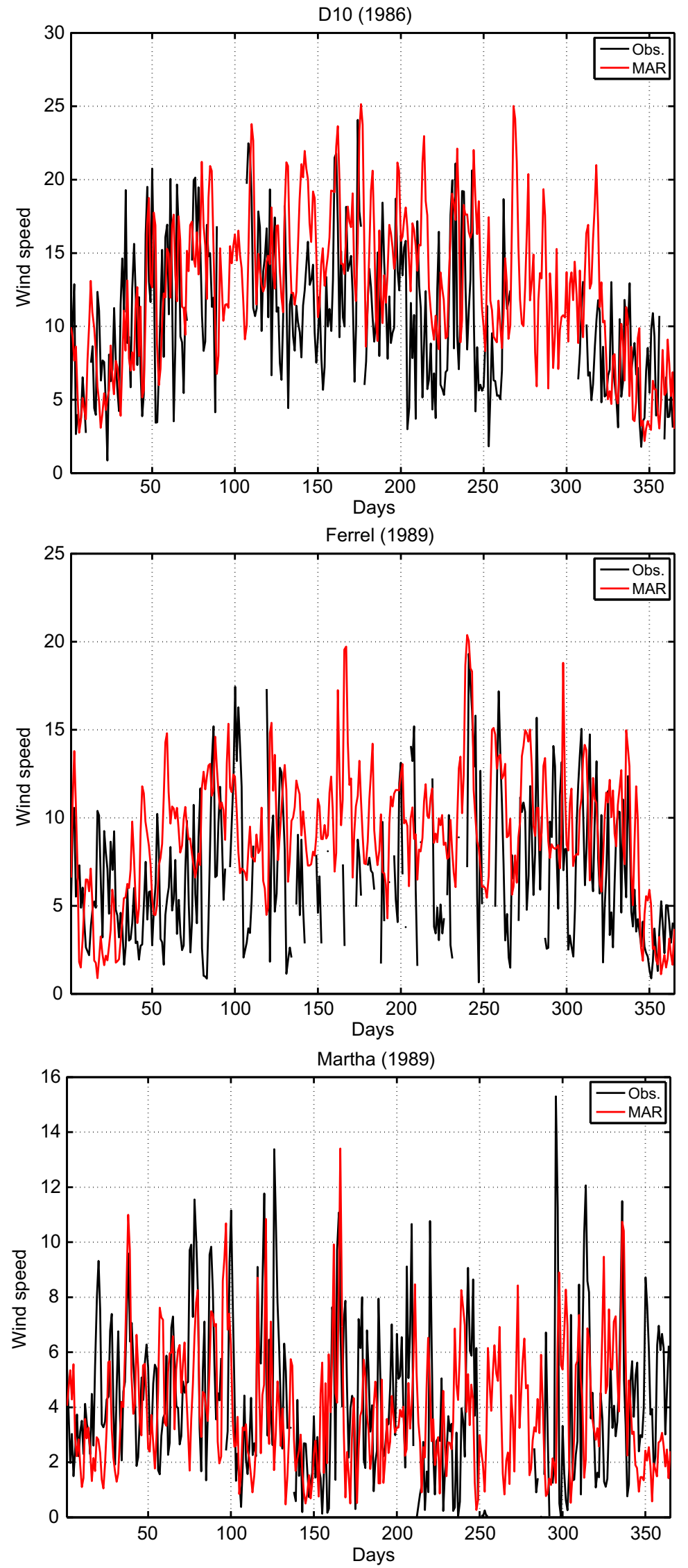

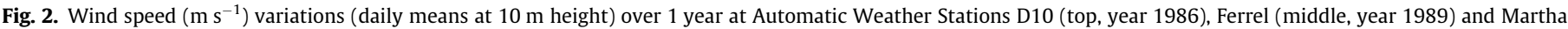

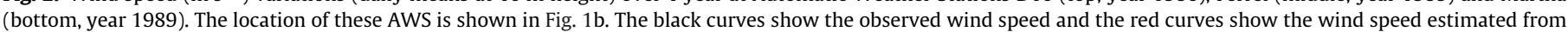
MAR wind stress (see text). (For interpretation of the references to colour in this figure legend, the reader is referred to the web version of this article.) 
Differences between the original ERA40 wind stress and that obtained by the downscaling by MAR are outlined below (for the 1980-1989 mean). We use here the usual frame of coordinates (i.e. the meridional/zonal components of the wind stress are positive northward/eastward, as shown in Fig. 1a-d). Note that for this comparison, both data sets are interpolated onto the ocean model $1 / 2^{\circ}$ grid that is used in Sections 4 and 5 to assess the effect of the katabatic wind on the ocean circulation and sea-ice.

\subsubsection{In the open sea}

Differences are fairly small in the open sea between the two wind stress fields, for both the zonal and meridional components (Fig. 1c and d). They generally do not exceed $\pm 0.01 \mathrm{~N} \mathrm{~m}^{-2}$, except between $120^{\circ} \mathrm{W}$ and $180^{\circ} \mathrm{W}$, where differences of both signs (positive or negative) reach above that value, the greatest difference being nearly about $0.05 \mathrm{~N} \mathrm{~m}^{-2}$ at $65^{\circ} \mathrm{S}$, MAR stress being greater.

\subsubsection{Along the coast of Antarctica}

Differences between the two mean wind stress fields are quite large in coastal areas for both the zonal and meridional components (Fig. 1c and d), and appear in patches. Positive differences in meridional wind stress largely dominate, and are localised in nine major patches (numbered in Fig. 1c and d). The positive anomalies near the Ross Ice Shelf (\#5) and the Antarctic Peninsula (\#7) correspond with greater alongshore winds in MAR (barrier winds along the Transantarctic Mountains and along the Antarctic Peninsula, respectively); the other patches around Antarctica correspond to greater off-shore winds in MAR (katabatic winds).

Differences in zonal wind stress also exhibit a patchy pattern with numerous negative anomalies all around Antarctica, demonstrating that the katabatic forcing of the coastal easterly winds is underestimated everywhere in ERA40.

The seasonal variation of the meridional stress component over the ocean along the coastline of Antarctica is shown in Fig. 3 and confirms that MAR yields stronger katabatic winds in winter. Ex- cept in the Bellingshausen Sea (\#6) where only MAR simulates katabatic winds during the beginning of winter, areas of strong katabatic winds (i.e. areas of maximum off-shore stress) are the same in MAR and ERA40 and exactly correspond to the patches of maximum differences outlined in Fig. 1c. All these results hold for the zonal component of the stress as well (no figure shown). Note however that at the Ross Ice Shelf (\#5), the wind stress signal in ERA40 is displaced to the East in comparison to MAR. Since MAR wind speed are consistent with observations along the Ross Ice Shelf (see Fig. 2 at AWS Martha and Ferrel), it is likely the position of maximum winds in this region is wrong in ERA40. This is a problem in the representation of the barrier winds along Transantarctic Mountains in ERA40. Barrier wind dynamics are not well represented in ERA40 but that shortcoming cannot be explained definitely. Barrier winds are generated by a pool of cold air which forms along the mountains, and which is fed partly by cold air coming from West Antarctica and partly by even colder air descending through the valleys of the Transantarctic Mountains. A possible candidate for the shortcoming in ERA40 could be the coarse vertical resolution near the surface, which does not allow representing accurately the strong stability of the low troposphere over the ice shelf.

Fig. 4 shows a scatter plot MAR versus ERA of all the data shown in Fig. 3. Two important features are outlined in this figure. First, MAR and ERA40 rarely have opposite wind stresses ( $8 \%$ for $\tau_{x}$ and $13 \%$ for $\tau_{y}$ ) and there is no offset for low winds (points are equally distributed around the blue line for stresses between $0.05 \mathrm{~N} \mathrm{~m}^{-2}<\tau_{x, y}<0.05 \mathrm{~N} \mathrm{~m}^{-2}$ ). Second, ERA40 stresses are smaller than MAR stresses for a wide majority of points (all points below the blue line, except for points which come from Ross Ice Shelf) for high stress values $\left(\tau_{x, y}>0.05 \mathrm{~N} \mathrm{~m}^{-2}\right.$ ). These results suggest that a katabatic correction for ERA40 stress or wind can be found in the form of a local amplification that is constant in time (i.e. no seasonal variation). This choice is mainly driven by simplicity, and an improvement would be to use a seasonal cycle in the correction.

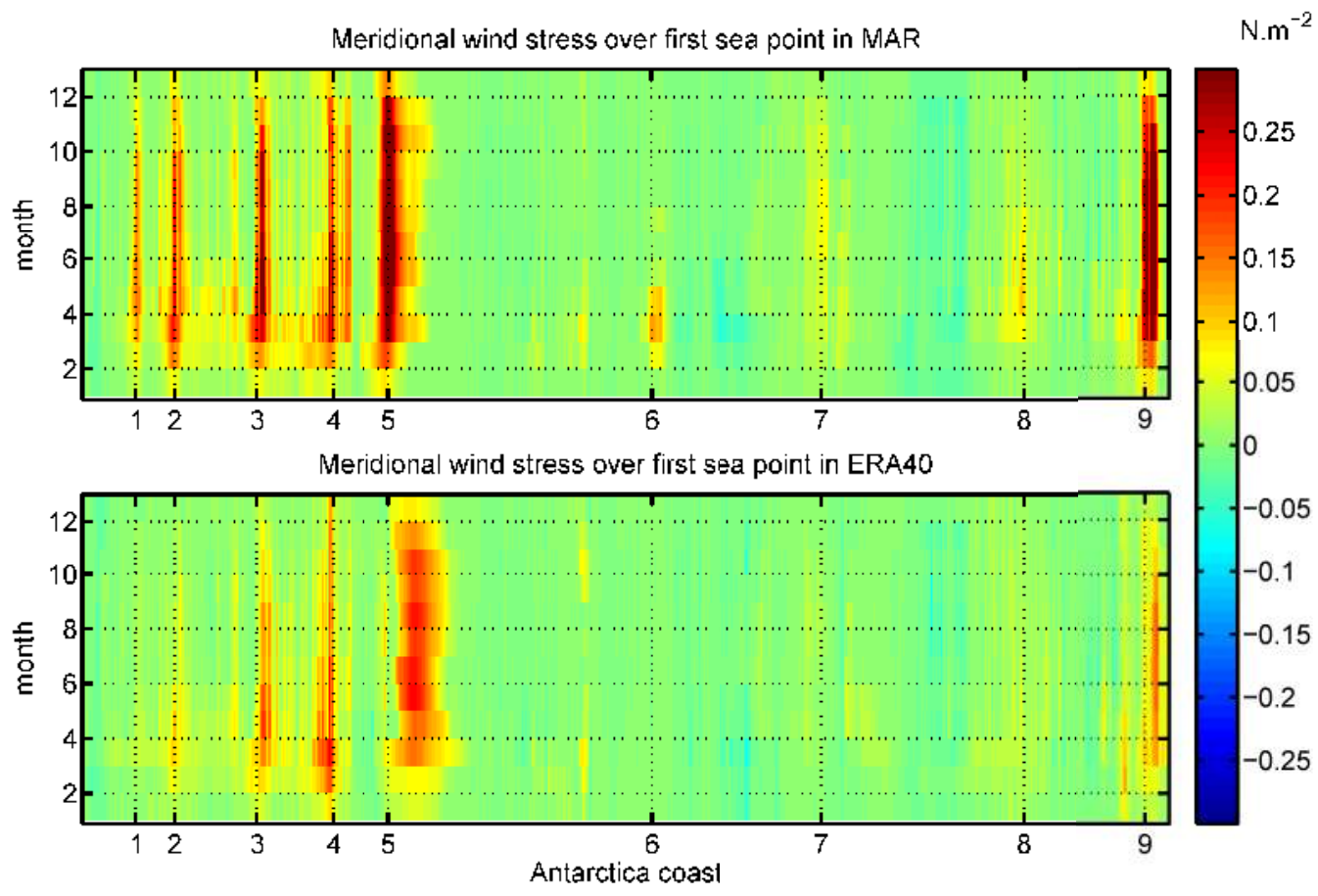

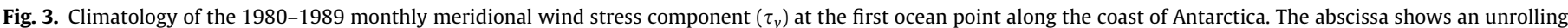

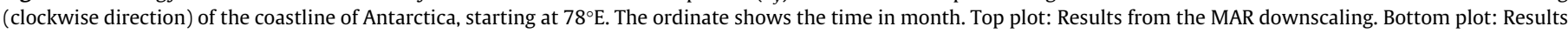
from ERA40. Numbers 1-9 locate the patches of greater off-shore winds in MAR outlined in Fig. 1c. 

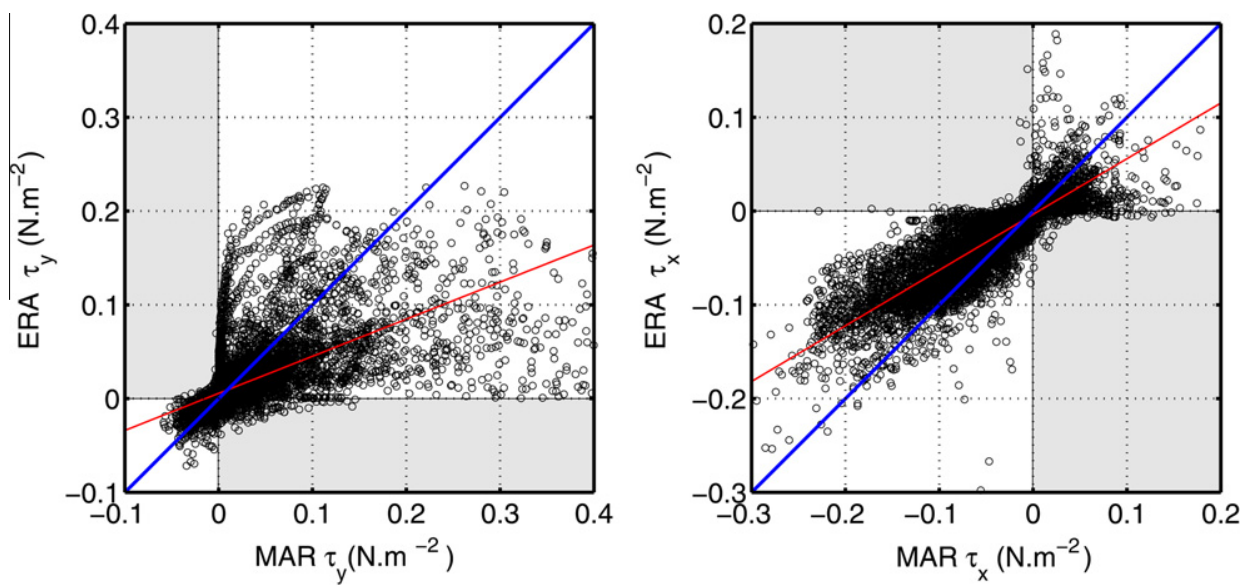

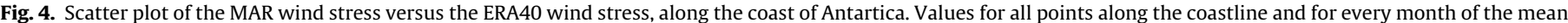

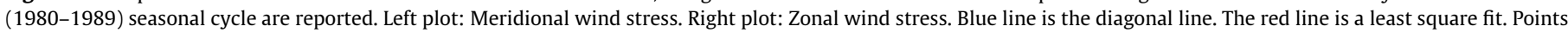

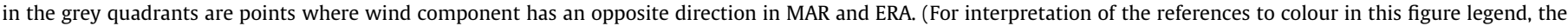
reader is referred to the web version of this article.)
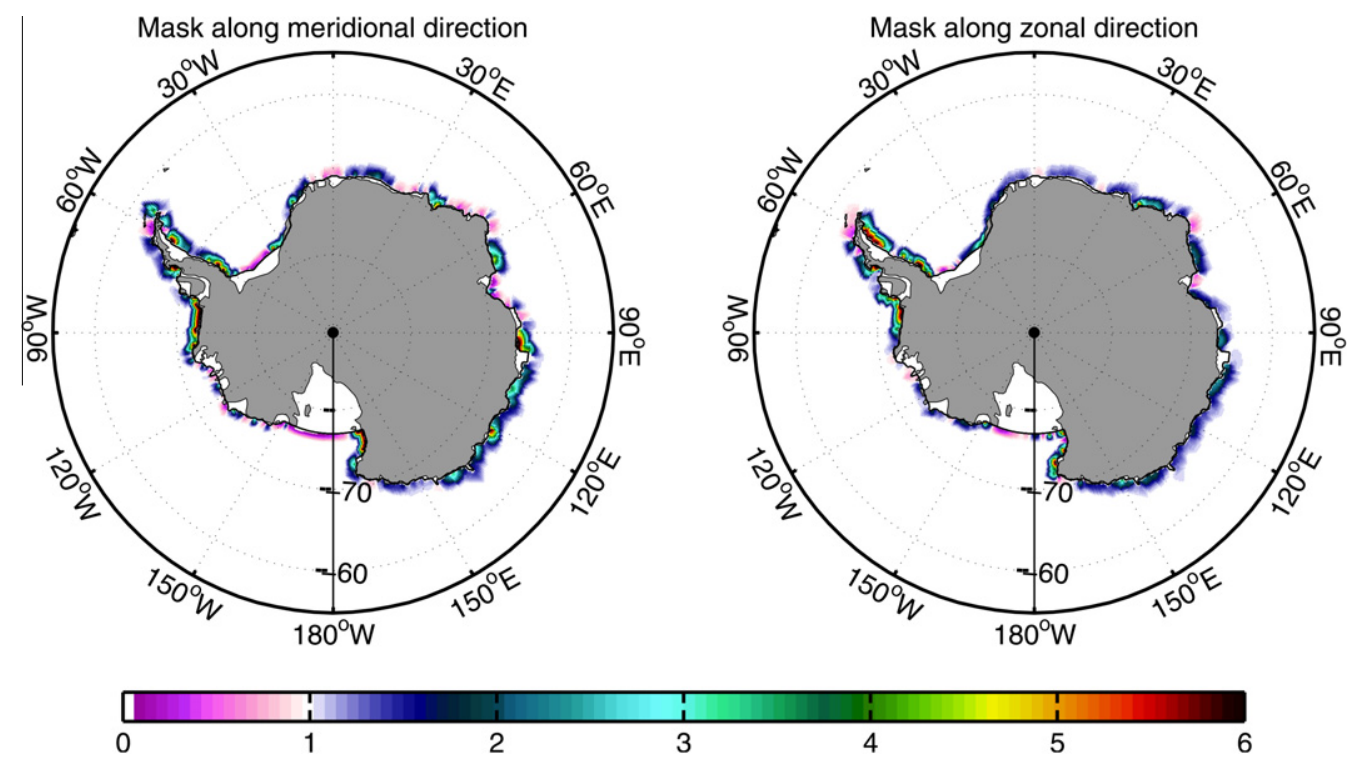

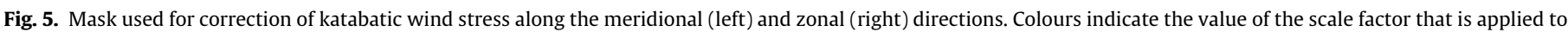

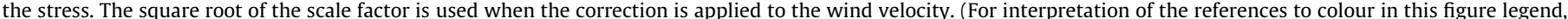
the reader is referred to the web version of this article.)

\section{Correction of katabatic winds}

Other studies have proposed corrections for katabatic winds in the ocean modelling community. Kim and Stossel (1998) proposed a basic correction in their coarse resolution ocean circulation mod$\mathrm{el}$, and fixed the wind to $20 \mathrm{~m} \mathrm{~s}^{-1}$ (northward) along the coast of the Bellingshausen Sea, the Amundsen Sea and the East coast, and to $10 \mathrm{~m} \mathrm{~s}^{-1}$ (northward) elsewhere. Roeske (2005) proposed to correct the meridional wind by the addition of an offset which is proportional to the difference between the wind over sea and the wind over land if the air temperature is below $0{ }^{\circ} \mathrm{C}$ (this correction decreases off-shore linearly over four grid points of the ECMWF model, i.e. $4.5^{\circ}$ ). Note that these corrections were applied only to the meridional component of the wind. However, the katabatic forcing also has a strong impact on the alongshore component of the wind as it is driving the strong easterly winds along the East coast of Antarctica, for example. This zonal component may also have a significant effect on the ocean and sea-ice processes near the coast (Davis and Mc Nider, 1997).
Following the findings of the previous section, the katabatic wind correction proposed here is defined as a scale factor (one for each component of the wind velocity vector) according to the following principles: the scale factor is spatially variable but constant in time; the values taken by the scale factor reflect the local ratio found between MAR and ERA40 stress components at the first ocean point; and the scale factor will be used to multiply the local 6-hourly ERA40 wind velocity components at ocean points near the coast.

The first step in the calculation of the scale factor is to average in time (over the 10-year period from 1980 to 1989) the wind stress components of MAR and ERA40 at the first ocean point along the coastline. The absolute value of the ratio of those two mean values (MAR over ERA40) is then calculated. This process yields a positive scale factor for each component at every coastal point, which varies from nearly zero (when MAR stress is very small) to over 20 (when ERA40 stress is very small). For practical reasons (i.e. the numerical stability of the ocean circulation model), too large values of the scale factor that may lead to very strong winds 

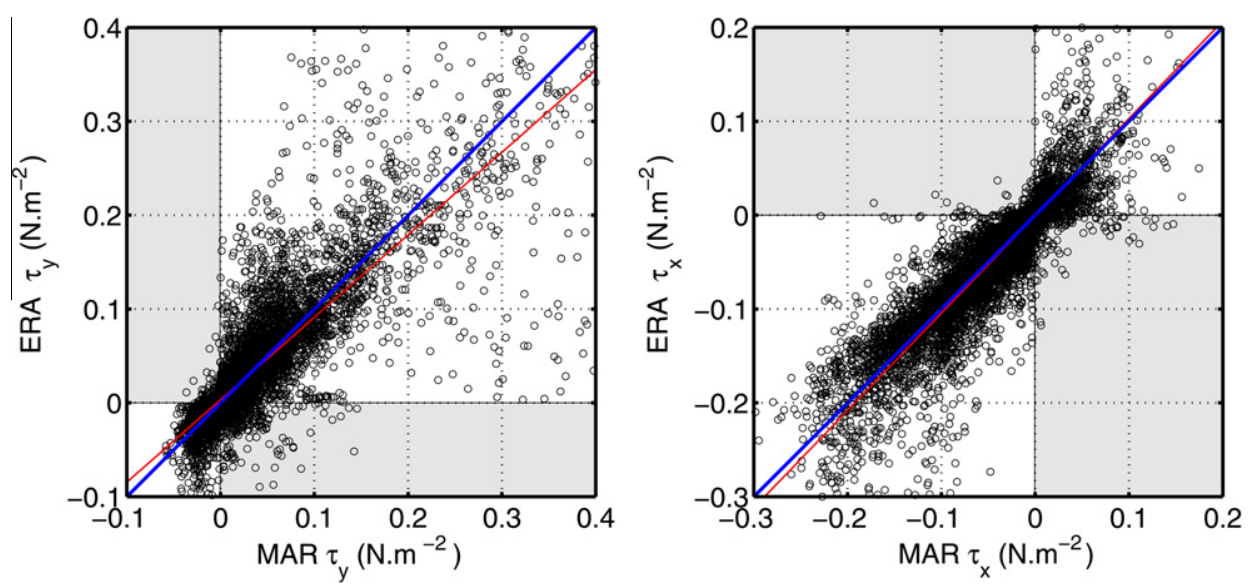

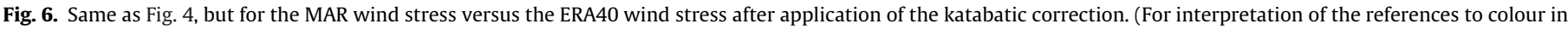
this figure legend, the reader is referred to the web version of this article.)

when applied to 6-hourly winds should be avoided. Based on the distribution of the scale factor at all points that has been calculated, we decided to limit its maximum value to 6 , which accounts for more than $81 \%(88 \%)$ of all points for zonal (meridional) direction.

The second step is to convert the wind stress scale factor (shown in Fig. 5) into a wind velocity scale factor to be used in the ocean model forcing bulk formulas. For simplicity, we do this by taking the square root of the stress scale factor, on the hypothesis that the link between the stress and the velocity is quadratic (as in the bulk formulae used to drive the model). Consequently, the maximum scale factor applied on each component of wind velocity is about 2.5 (which yield a maximum possible amplification of the wind speed by a factor of 3.5). The application of a scale factor for each component might slightly modify the direction of the wind velocity vector, but it never reverses it.

Finally, to avoid a too strong wind curl at the coast, the scale factor is extended toward the open ocean, varying from its coastal value to the value of unity as a cosine function over a distance of about $150 \mathrm{~km}$ (roughly the typical size of the patches seen in Fig. 1). This yields a smooth transition between the coastal areas influenced by katabatic winds and the open sea.

The scale factors for both wind stress components are shown in Fig. 5 (simply take the squared root to obtain the scale factor used for the wind in the model simulations of Sections 4 and 5). It shows a patchy pattern similar to that exhibited by the differences between MAR and ERA40 in Fig. 1. Especially strong values are found in the Bellingshausen Sea, along the Antarctic Peninsula, and along the East Antarctic coast $\left(150^{\circ} \mathrm{E}, 90^{\circ} \mathrm{E}\right)$. The scale factor is greater in the zonal direction than in the meridional direction in many places around Antarctica. It is also smaller than 1 in a few locations (pink area in Fig. 5), along the Ross Ice Shelf, the Ronne Ice Shelf in the Weddell Sea, and the Amery Ice Shelf in Prydz Bay for example. In the Ross Sea area, this is due to a misrepresentation of the barrier winds along the Transantarctic Mountains in ERA40 as shown by Mathiot et al. (submitted for publication).

The seasonal values of wind stress from MAR and from the corrected ERA40 along the first point along the coast shown in Fig. 6, indicate that the katabatic correction defined on the climatological mean adequately corrects the seasonal cycle as well, the correction slightly overestimating (underestimating) the zonal (meridional) component for strong winds.

This correction has been applied to ERA40 wind stress over the whole period (1958-2001) of several simulations of the DRAKKAR project (DRAKKAR-Group, 2007). In the next two sections, we ap- ply it to the ERA40 wind velocity vector that drives a global ocean/sea-ice model to better understand the importance of the katabatic winds on the ocean circulation.

\section{Ocean circulation model}

The effect of katabatic winds on ocean/sea-ice dynamics is assessed through twin experiments performed with the global ocean sea-ice DRAKKAR configuration ORCA05 (resolution of $0.5^{\circ}$ ). This section briefly describes the ORCA05 configuration and the atmospheric forcing (including the application of the katabatic correction) used over the period 1958-2001.

\subsection{Model configuration}

ORCA05 is part of an ocean/sea-ice model hierarchy implemented globally at different resolutions by the DRAKKAR project (DRAKKAR Group, 2007) based on the NEMO code (Madec, 2008). The ocean GCM is OPA9, a free surface primitive equation numerical code, and the sea-ice code is the LIM2 code (Fichefet and Morales Maqueda, 1997). The nominal, nearly isotropic grid resolution of ORCA05 (shared by the ocean and sea-ice models) is $1 / 2^{\circ}$ ( $\sim 25 \mathrm{~km}$ at $60^{\circ} \mathrm{S}$ and $\sim 15 \mathrm{~km}$ in the Ross Sea and Weddell Sea). The vertical resolution comprises 46 levels with an increase of resolution near the surface $(6 \mathrm{~m}$ in surface and $200 \mathrm{~m}$ near the bottom). Surface boundary layer mixing and interior vertical mixing are parameterised according to a turbulent kinetic energy closure model (see the NEMO reference manual, Madec (2008)). The Bottom boundary layer parameterisation used is based on Beckmann and Doesher (1997). Bottom topography is represented as partial steps. Barnier et al. (2006) describe the $1 / 4^{\circ}$ version (ORCA025) of this $1 / 2^{\circ}$ model in details. According to its four-times-coarser horizontal resolution, parameters used in ORCA05 for horizontal biharmonic viscosity and isopycnal laplacian diffusivity are multiplied by 8 and 2, respectively, with respect to their ORCA025 counterparts. The ORCA05 model version used here also differs from the model described in Barnier et al. (2006) by its use of the CORE bulk formulae (Large and Yeager, 2004).

The ORCA05 model yields a reasonable representation of western boundary currents, and of the Antarctic Circumpolar Current. It also captures the various processes of deep-water formation due to the thermohaline and wind forcing, although it does not resolve mesoscale processes. ORCA05 has been demonstrated to adequately simulate the decadal MOC variability simulated by models 


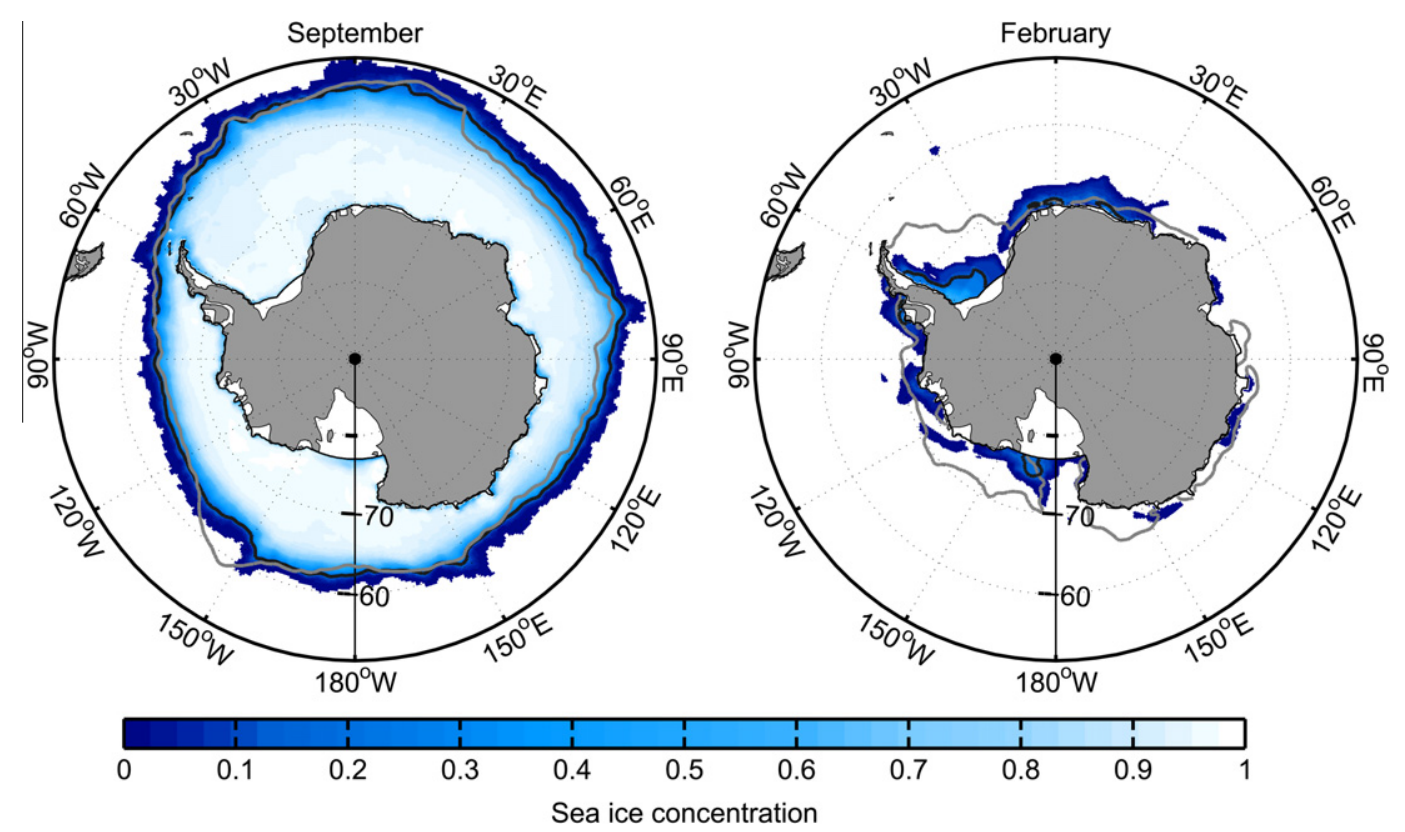

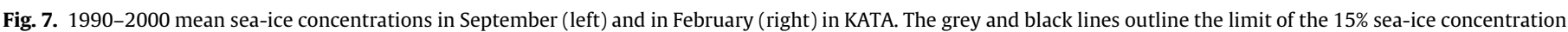
in the SSMI observations and the KATA simulation, respectively.

at higher resolution (Biastoch et al., 2008a). Note that cavities under ice shelves are not represented or parameterised in the model.

\subsection{Forcing fields}

The ORCA05 model is driven over the period 1958-2001 by the DFS3 forcing function developed for the DRAKKAR project. As detailed in Brodeau et al. (2010), DFS3 combines elements from two sources: the CORE forcing data set (Large and Yeager, 2004), from which precipitation (rain and snow), downward shortwave and longwave radiations are extracted; and the ERA40 reanalysis (Simmons and Gibson, 2000) which provides $10-\mathrm{m}$ wind, air humidity and air temperature used by the bulk formulae to compute turbulent air/sea and air/sea-ice fluxes online. The frequency of DFS3 is monthly for precipitation, daily for radiation and 6hourly for turbulent variables. This forcing function is interpolated onto the ORCA05 grid.

\subsection{Simulation strategy}

Two experiments are performed over the period 1958-2001: without the katabatic wind correction and with katabatic wind correction applied to the wind velocity vector. The correction is applied as follows. The zonal and meridional components of the $10-\mathrm{m}$ ERA40 6-hourly wind are multiplied by the squared root of the scale factor shown in Fig. 5. Then, the corrected wind is used in the model bulk formulae to calculate the fluxes driving the model (i.e. wind stress, sensible and latent heat fluxes, evaporation). Therefore, the katabatic correction impacts the mechanical, thermal and freshwater forcing. The simulation using the original DFS3 forcing is referred to as DFS3. The simulation using the katabatic wind correction is referred to as KATA

\subsection{Model solution in the vicinity of Antarctica}

ORCA05 has been used in a series of studies, and the good behaviour of the model in its representation of many ocean circulation features has been demonstrated, in the limit of the resolution used (Lachkar et al., 2007; Biastoch et al., 2008a,b). At Drake
Passage, for example, the net transport in the KATA simulation is about $127 \mathrm{~Sv}$ when averaged over the period 1990-2000. It compares reasonably well with estimates derived from observations, although on the low side (Cunningham et al., 2003, estimate the transport across the Drake passage to be $136.7 \pm 7.8 \mathrm{~Sv}$ during the period 1993-2000 from CTD and ADCP data at the SR1 WOCE section). However, little has been published from this model on the way it simulates the major features of the sea-ice in the vicinity of Antarctica. This issue is approached in the present section, which compares the model sea-ice extent with observations from SSMI (Cavalieri et al., 1997), and the model sea-ice thickness with observations from the ASPECT data set (Timmermann et al., 2004; Worby et al., 2008). The comparison is made for the KATA simulation only.

The definition of the sea-ice extent used here follows Fetterer and Knowles (2004); it is the area where sea-ice concentration is greater than $15 \%$. The winter-mean (1990-2000) sea-ice extent is rather well simulated (September in Fig. 7): the 15\% sea-ice concentration lines of both SSMI and KATA often line-up around Antarctica, and the sea-ice areas they define are similar within 5\% (19.520 million $\mathrm{km}^{2}$ in KATA and 18.820 million $\mathrm{km}^{2}$ in SSMI data). The only significant discrepancy is a localised underestimation of the sea-ice extent at $150^{\circ} \mathrm{W}$, and a slight overestimation between $30^{\circ} \mathrm{E}$ and $120^{\circ} \mathrm{E}$. The presence of polynyas along the coast of Antarctica (darker blue areas) is also noteworthy in Fig. 7.

On the contrary, the model sea-ice extent is not well represented in summer (February, Fig. 7). The cumulative Southern Ocean sea-ice extent is 0.31 million $\mathrm{km}^{2}$ in KATA against 2.92 million $\mathrm{km}^{2}$ in SSMI data, an underestimation by nearly a factor of 10 . It is very likely that a significant contribution to this flaw comes from the DFS3 forcing fields in the open ocean as pointed out by Mathiot et al. (submitted for publication) in the Ross Sea. Other regional experiments carried out with MAR and DFS3 forcing fields (Mathiot, 2009, no figure shown) indicate that this problem is at least partly due to ERA40 temperature (too warm) and winds, but the parameters of the LIM2 sea-ice model itself also contribute. The model sea-ice thickness is compared to the ASPeCt data. Using the collocation algorithm of Juza et al. (submitted for publication), based on an interpolation scheme quadrilinear in space 

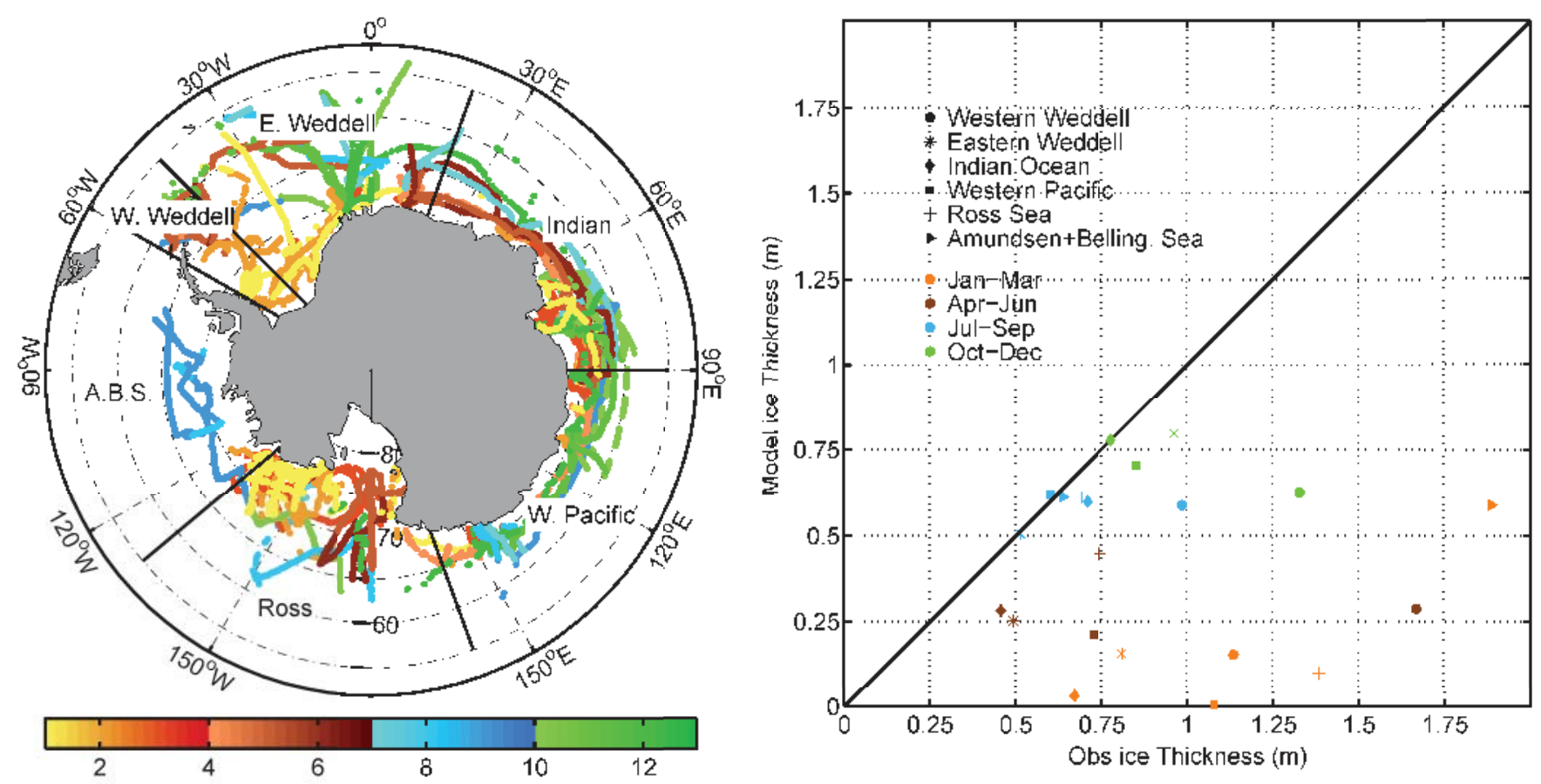

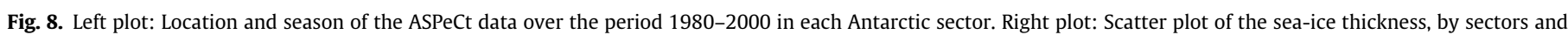

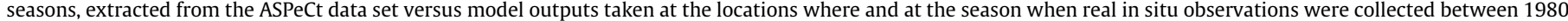
and 2000. Colours identify seasons and the shapes of markers identify sectors.

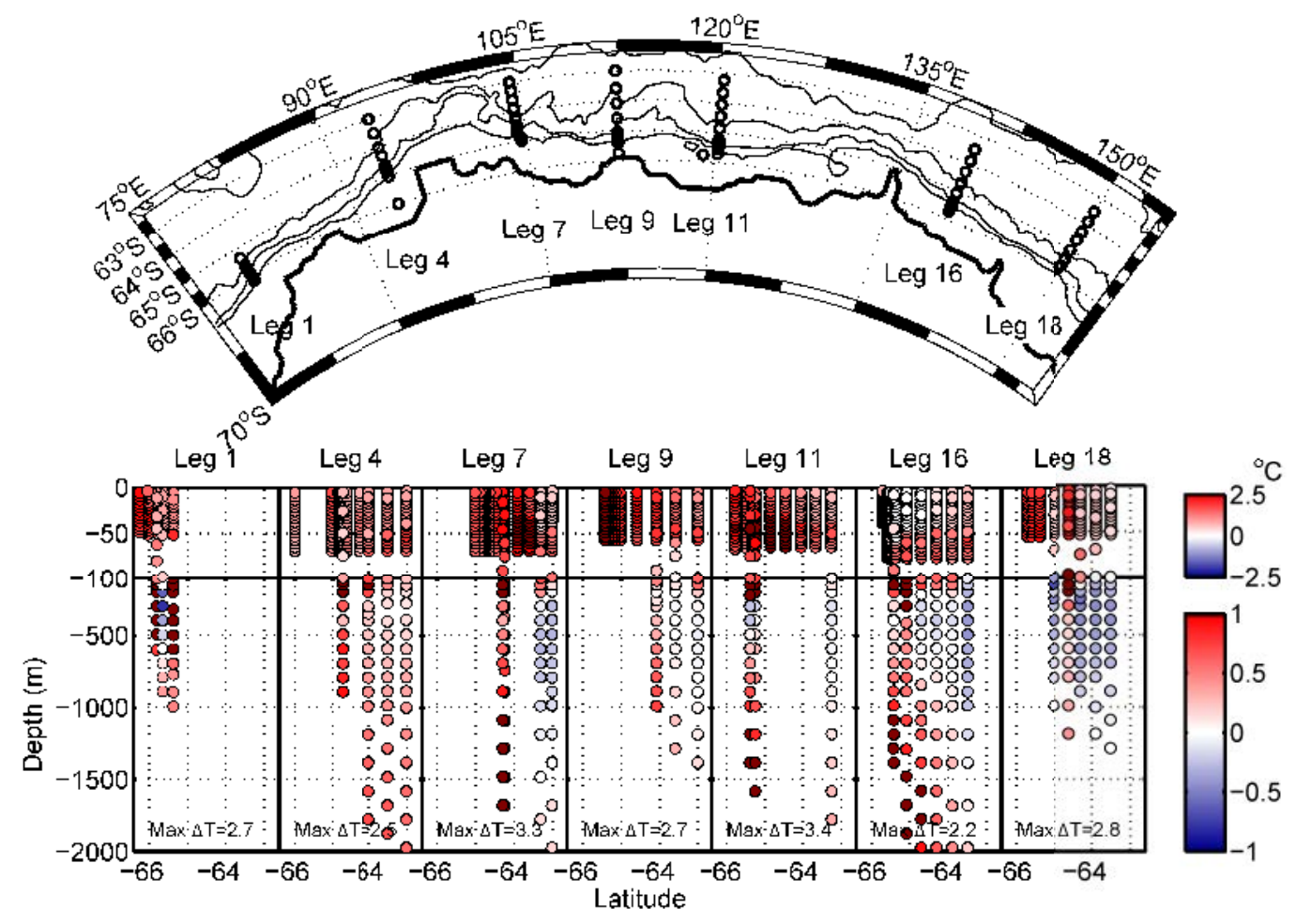

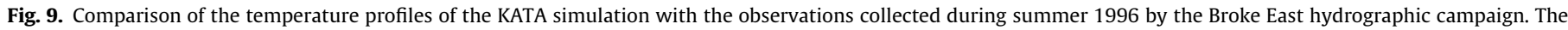

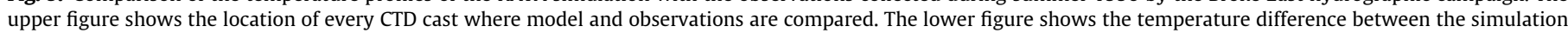

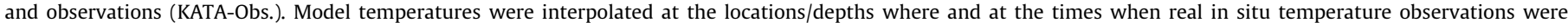

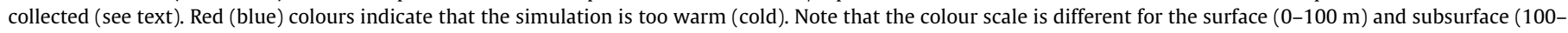

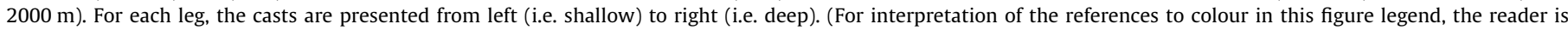
referred to the web version of this article.)

and time, synthetic sea-ice thickness data from the KATA model simulation are obtained at the locations where and at the times when real in situ observations were collected during ASPeCt.
The collocated model and observed sea-ice thickness data are compared by seasons and by geographical sectors in the scatter plot of Fig. 8. The model always produces a thinner sea-ice than 
observed, but differences between model and observations greatly vary according to the sector and the season. In winter (July-September), just as for the sea-ice extent, the sea-ice thickness compares rather well with observations in all sectors, excepted in the Weddell Sea where the model sea-ice is $60 \%$ of the observed value. In spring (October-December), the agreement with observations is still good, except for the Western Weddell Sea and the Amundsen Sea. In summer (January-March) and fall (April-June), the sea-ice has considerably melted in the simulation (as shown in Fig. 8), and the remaining sea-ice is also considerably too thin. Similar results were found by Timmermann et al. (2004) in simulations using a former version of the present ocean/sea-ice model at coarser resolution $\left(2^{\circ}\right)$.

We also compared the model results with the observed temperature profiles collected in summer 1996 along the East coast of Antarctica by the Broke East hydrographic survey (Bindoff et al. 2000). These observations were obtained from the ENACT-ENSEMBLES EN3_v2a dataset (Ingleby and Huddleston, 2007). Using again the collocation algorithm of Juza et al. (submitted for publication), synthetic temperature data from the KATA model simulation are obtained at the locations/depths where and at the times when real in situ temperature observations were collected by the hydrographic survey. The differences between model and observations are shown in Fig. 9. The model shows similar flaws at every leg. Near the surface $(0-100 \mathrm{~m})$ model waters are too warm $\left(+2{ }^{\circ} \mathrm{C}\right.$ at many stations). In subsurface (100-2000 m), model waters are too warm along the continental slope $\left(\sim 0.3^{\circ} \mathrm{C}\right.$ at Legs $1,4,7,11$, 16) and too cold in the open sea (i.e. north of $64^{\circ} \mathrm{S}$ ) by about $0.3^{\circ} \mathrm{C}$. The warm bias of surface waters likely contributes to the excessive summer melting seen in the model, but feedback processes make the picture more complex. The excessive sea-ice melting results in an increase of shortwave penetration (because of an increase of open water), and injects more freshwater at the surface. This in turn increases the stratification and the warming of the upper ocean.

Although the model solution presents significant biases in its representation of the summer situation, the simulation of winter and spring compares reasonably well with observations. This is quite enough for the purpose of testing the katabatic correction, since the correction is expected to have its major impact on ocean and sea-ice when katabatic winds are the strongest, i.e. in winter and spring or during the coastal polynya season (Fig. 3).

\section{Impact of katabatic winds}

Katabatic winds are known to be one of the main factors driving polynya dynamics around Antarctica. Massom et al. (1998) showed that $60 \%$ of the polynyas found along the East coast are forced, at least partly, by katabatic winds (the Mertz Glacier Polynya or Terra Nova Bay Polynyas for example). Dense Antarctic waters are primarily formed on the Antarctic shelf by formation of sea-ice during winter months. This process is assisted by coastal polynyas. The strong cooling and salting (due to brine rejection) of the surface ocean during episodes of sea-ice formation in polynyas yield a strong vertical mixing in the water column and result in formation of dense waters on the shelf (Gill, 1973). This water spreads along shelf topography before sinking along continental slopes (a useful schematic view of this process can be found in Baines and Condie (1998).

The following analysis of the twin simulations KATA and DFS3 focuses on the response of polynyas, sea-ice, hydrography and circulation south of $60^{\circ} \mathrm{S}$ to katabatic winds. Results presented below concern time averaged properties over the last decade (1990-2000) of the 1958-2001 period covered by the simulations.

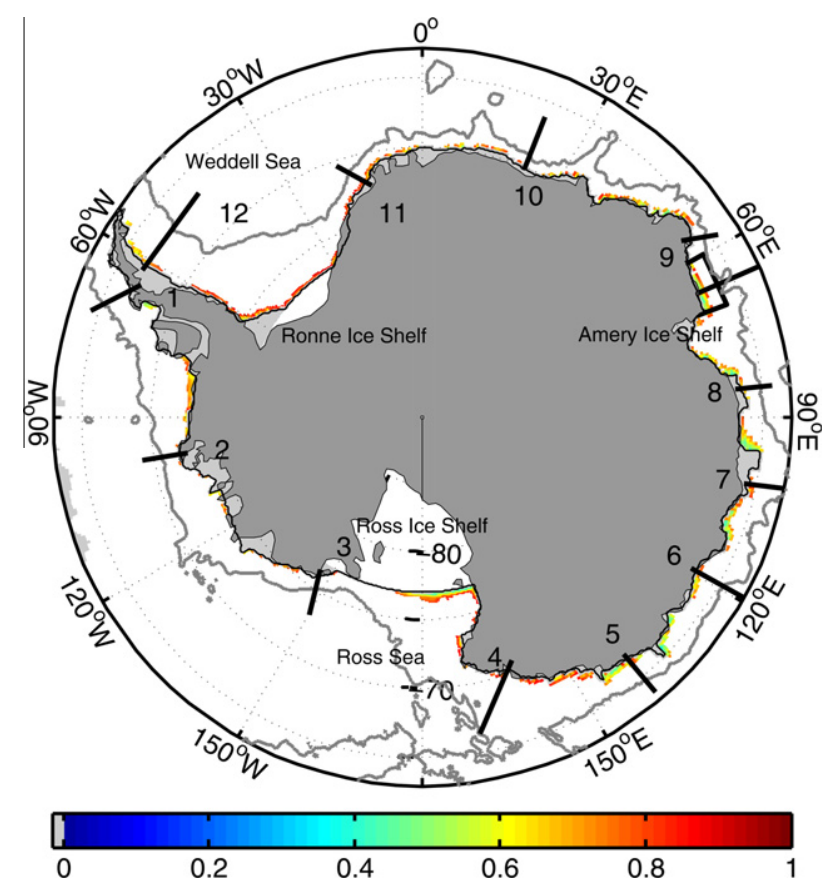

Fig. 10. Polynya area selected in KATA during July 1990-2000 by the polynya criterion: ice production greater than $0.7 \mathrm{~m}$ per month and an ocean depth less than $1200 \mathrm{~m}$. Colours indicate sea-ice fraction in polynya. Black lines (from 1 to 12 ) are sections used in Fig. 16, the black box near $60^{\circ} \mathrm{E}$ is the box used for the T, S diagram of the Cape Darnley polynya in Fig. 14, and the long black line (without numbering) in the black box is the section plotted in Fig. 15. The $3000 \mathrm{~m}$ isobath, used as the Northern end of the transport calculation in Fig. 16, is shown in grey.

\section{Impact on sea-ice in Polynyas}

Coastal polynyas exhibit a large rate of sea-ice production on shelf areas. Therefore, we define here as polynyas areas which satisfy the following twofold criterion: ice production greater than $0.7 \mathrm{~m}$ per month; and ocean depth shallower than $1200 \mathrm{~m}$.

With this criterion, coastal polynyas are strictly limited to small areas of a few tens of kilometres spread along the continent (note that ice fraction can be lower than $40 \%$ in polynyas as shown by the map displayed in Fig. 10).

The global characteristics of the Antarctic coastal polynyas in winter are compared in the two simulations (Table 1). Note that all polynyas detected by the criterion contribute to the cumulated/averaged characteristics (see Table 1 legend). The katabatic correction induces a $114 \%$ increase of the wind stress in average over all the polynya areas $\left(0.15 \mathrm{~N} \mathrm{~m}^{-2}\right.$ in KATA and $0.07 \mathrm{~N} \mathrm{~m}^{-2}$ in DFS3). Sensible and latent heat fluxes are increased by $28 \%$ and $17.8 \%$, respectively. This yields a $24 \%$ increase of the total surface of polynyas (from 250,000 to $310,000 \mathrm{~km}^{2}$ ) and a $42 \%$ increase of winter sea-ice production (from $1.77 \times 10^{3}$ to $2.51 \times 10^{3} \mathrm{~km}^{3}$ ) in KATA compared to DFS3.

The total polynya area corresponds to about $1.9 \%$ of the total sea-ice extent of Antarctica in the KATA simulation $1.5 \%$ in DFS3), but the ice produced in these areas represent a significant portion of the total sea-ice produced around Antarctica in winter (16\% in KATA and $12 \%$ in DFS3). Tamura et al. (2008) describe a qualitatively similar activity for 13 major polynyas around Antarctica. Using sea-ice data from satellite and atmospheric reanalysis data (ERA40 and NCEP), they estimate that while representing $1 \%$ of sea-ice cover, these polynya areas produce $10 \%$ of the total sea-ice in Southern Ocean. The relevance of a more quantitative comparison of the model results with the analysis of Tamura et al. (2008) is difficult to assess, because the greater values of 
Table 1

Global winter-mean characteristics of coastal polynyas in the simulations KATA and DFS3. The winter-mean covers a period of 6 months from April to September. Global means here are averaged over the period 1990-2000, and averaged around the whole Antarctica (but only over the areas where the polynya criterion is verified).

\begin{tabular}{lll}
\hline Simulation & $\begin{array}{l}\text { DFS3 } \\
\text { original } \\
\text { wind }\end{array}$ & $\begin{array}{l}\text { KATA } \\
\text { corrected } \\
\text { wind }\end{array}$ \\
\hline Wind stress in polynya $\left(\mathrm{N} \mathrm{m}^{-2}\right)$ & 0.07 & 0.15 \\
Sensible heat flux $\left(\mathrm{W} \mathrm{m}^{-2}\right)$ & -44.8 & -57.3 \\
Latent heat flux $\left(\mathrm{W} \mathrm{m}^{-2}\right)$ & -100.6 & -118.5 \\
Total turbulent heat flux $\left(\mathrm{W} \mathrm{m}^{-2}\right)$ & -145.4 & -175.8 \\
Polynyas extent $\left(\times 10^{6} \mathrm{~km}^{2}\right)$ & 0.25 & 0.31 \\
Total sea-ice extent $\left(\times 10^{6} \mathrm{~km}^{2}\right)$ & 15.95 & 16.00 \\
Portion of total sea-ice extent represented by polynyas & $1.5 \%$ & $1.9 \%$ \\
Ice production rate in polynyas $\left(\times 10^{3} \mathrm{~km}^{3} / \mathrm{month}^{2}\right)$ & 0.30 & 0.42 \\
Ice production rate in polynyas per unit area $(\mathrm{m} /$ & 1.20 & 1.36 \\
$\quad$ month) & 1.77 & 2.51 \\
Ice volume produced in polynyas $\left(\times 10^{3} \mathrm{~km}^{3}\right)$ & 2.49 & 2.55 \\
Total ice production rate $\left(\times 10^{3} \mathrm{~km}^{3} / \mathrm{month}^{3}\right)$ & 14.93 & 15.31 \\
Total ice volume produced $\left(\right.$ in $\left.\times 10^{3} \mathrm{~km}^{3}\right)$ & $12 \%$ & $16 \%$ \\
Portion of total ice produced in polynyas & -1.63 & -1.62 \\
SST in polynyas $\left({ }^{\circ} \mathrm{C}\right)$ & 34.05 & 34.10 \\
SSS in polynyas & 36.83 & 36.87 \\
Surface potential density $\sigma_{2}$ in polynyas $\left(\mathrm{kg} \mathrm{m}^{-3}\right)$ & 2.98 & 4.76 \\
Export of HSSW out of polynyas $($ in Sv) & & \\
\hline
\end{tabular}

Sea ice production (KATA-DFS3) in $\mathrm{m} /$ month

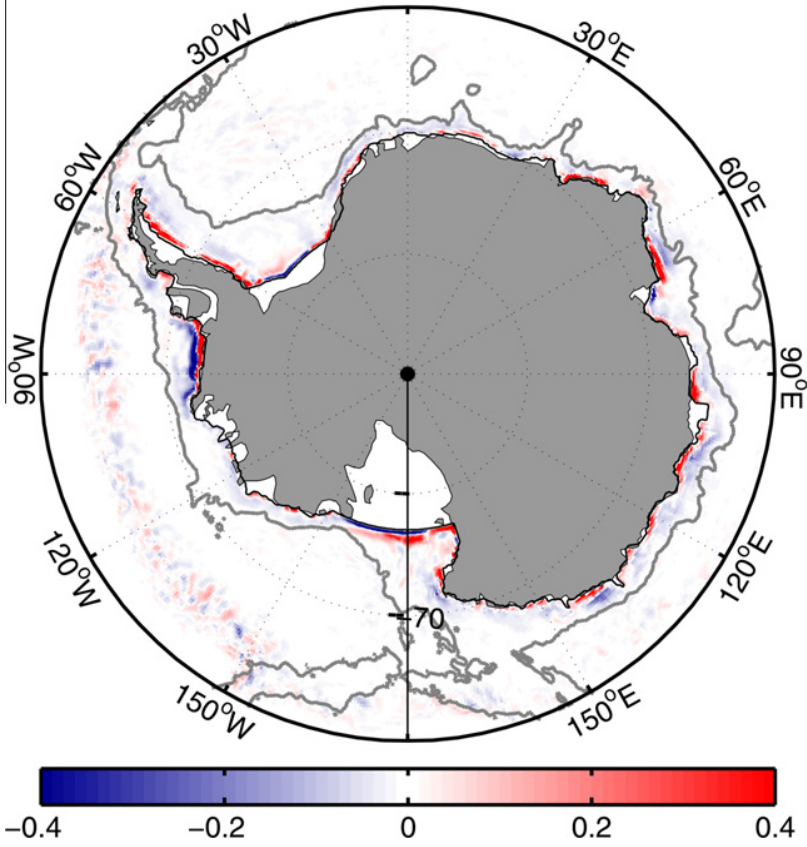

Fig. 11. Difference in sea-ice production between KATA and DFS3 simulations in September. Units are $\mathrm{m} / \mathrm{month}$. Areas adjacent to the coast, where the absolute value of the difference is greater than 0.2 , correspond to polynyas. Red/blue colour indicates a greater/smaller ice production in KATA (i.e. when the katabatic wind correction is used). Note that when ice production in KATA is greater (or smaller) in a polynya, it is systematically smaller (or greater) in the open sea. (For interpretation of the references to colour in this figure legend, the reader is referred to the web version of this article.)

the model simulations could be due to the criterion used to distinguish between polynyas and the ice pack, but also to the polynyas studied (all polynyas in KATA and DFS3, and only 13 in Tamura et al. (2008)); and in the assumption made by these authors to compute the total sea-ice production in the southern ocean (e.g. they assume a uniform thickness of $1 \mathrm{~m}$ for the whole ice pack). The regional model study of Marsland et al. (2004), also describe a similar activity for the Mertz Glacier Polynya. These authors esti- mate that this later polynya alone represents about $0.1 \%$ of sea-ice area in Antarctica and produced about $1.2 \%$ of total sea-ice produced in the Southern Ocean. Therefore, the katabatic correction has a clear positive impact on the model solution, noticeably increasing the activity and productivity of the coastal polynyas.

\subsection{Impact on total sea-ice}

The katabatic correction does not significantly impact the total sea-ice extent or volume (Table 1). The small increase of the total sea-ice volume in KATA $\left(380 \mathrm{~km}^{3}\right.$, i.e. $2.5 \%$, or a $2.2 \mathrm{~cm}$ increase in sea-ice thickness) does not match the additional $740 \mathrm{~km}^{3}$ of sea-ice produced in the polynyas, which indicates that the net ice production (freezing and melting) outside the polynyas is lesser in KATA during the winter. Indeed, ice production is reduced in the areas of the open ocean immediately adjacent to the polynyas (Fig. 11). This compensating effect sensibly reduces the effect of the katabatic wind correction on the total sea-ice budget around Antarctica.

This effect is due to an increase of warmer surface water inflow in polynya area (no figure shown), which diminishes sea-ice production. Nevertheless over the whole Southern Ocean ice pack, the decrease of sea-ice production outside polynyas does not totally compensate for the greater sea-ice formation in polynya regions.

Obvious consequences of the katabatic correction are a marked decrease of the sea-ice thickness (by 10-20 cm, Fig. 12) and of the ice-fraction (by 5\%, no figure shown), and a noticeable increase of the ice production (more than $0.2 \mathrm{~m} / \mathrm{month}$, Fig. 11) in a narrow band around Antarctica, although many local exceptions are found at the Ross Sea-Ice shelf, the Ronne Ice Shelf, the Larsen Sea coast $\left(30^{\circ} \mathrm{E}\right)$ and the Prydz Bay along Amery Ice Shelf where it is the opposite. (This was expected since the scale factor of the correction is smaller than 1 in these regions, see Fig. 5). Note also that coastal areas marked by a decrease (or increase) in sea-ice thickness are rather well correlated with areas (shown in Fig. 5) where the

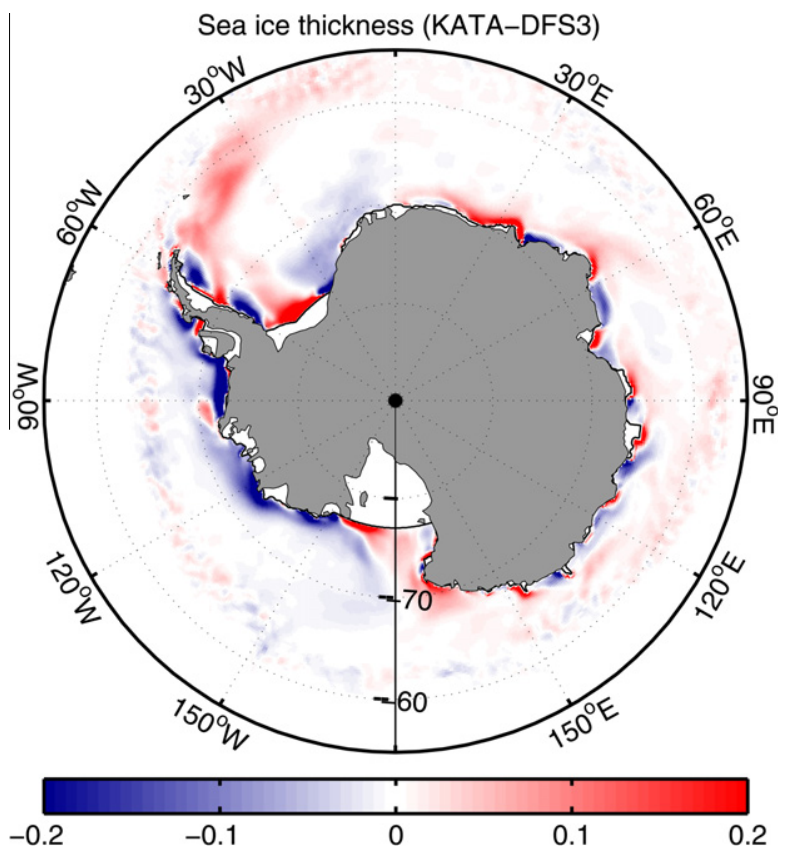

Fig. 12. Differences in sea-ice thickness between KATA and DFS3 (in meters) in September. In red (blue): areas where sea-ice is thicker (thinner) in KATA simulation. (For interpretation of the references to colour in this figure legend, the reader is referred to the web version of this article.) 

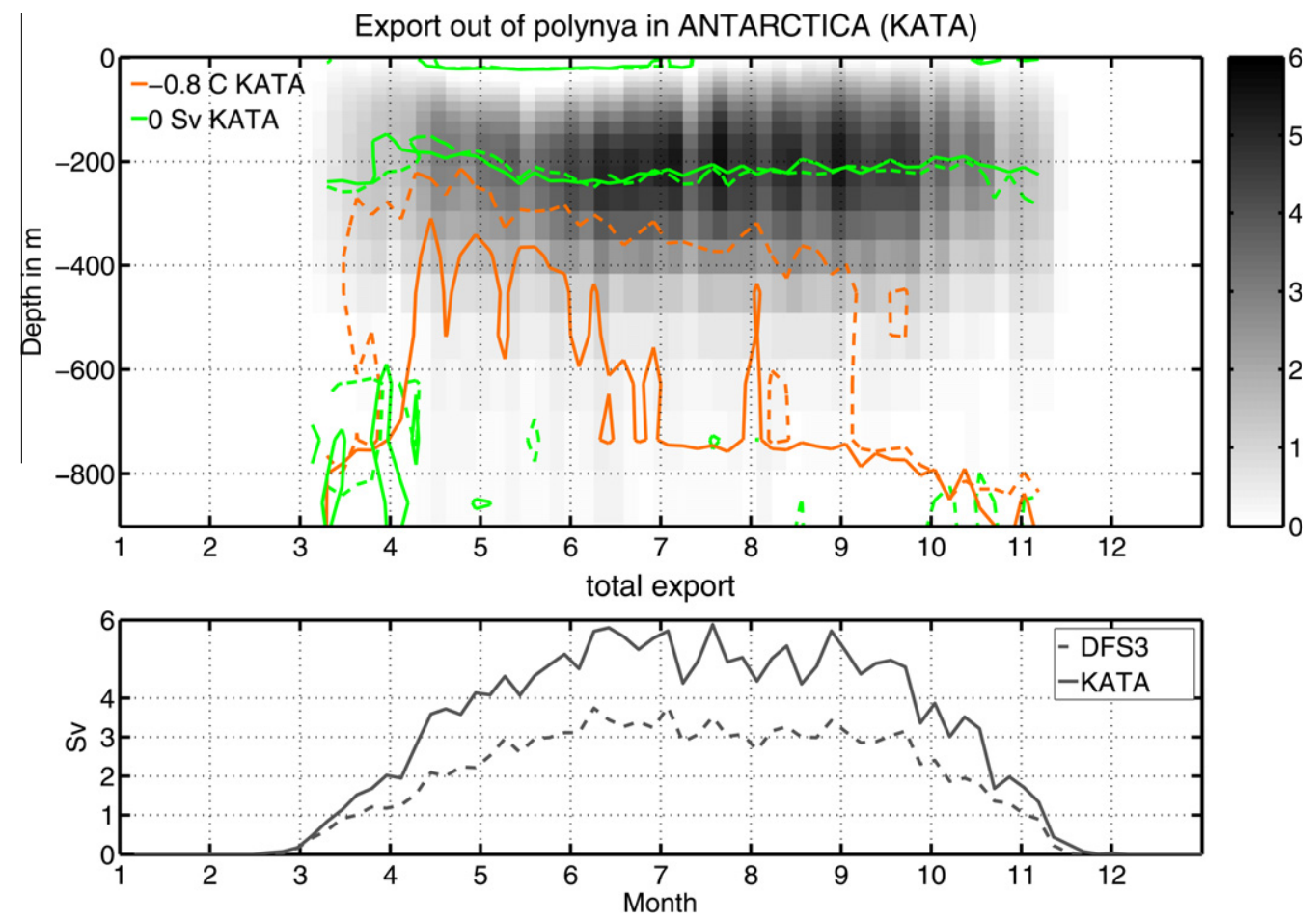

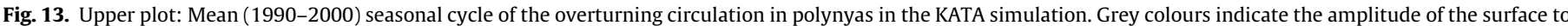

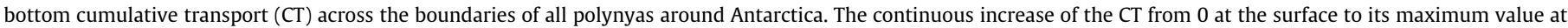

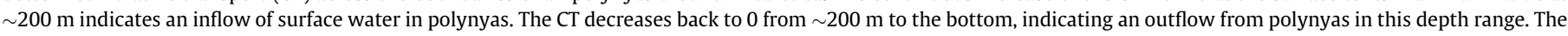

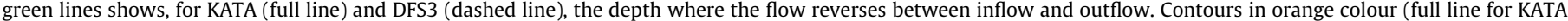

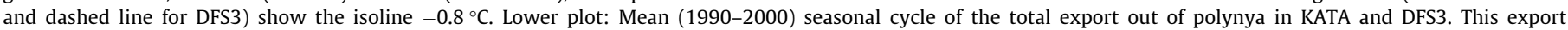

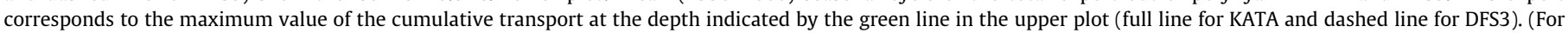
interpretation of the references to colour in this figure legend, the reader is referred to the web version of this article.)

correction factor for the off-shore component of the wind is greater (or smaller) than 1.

\subsection{Impact on ocean properties in polynyas}

Polynyas are often associated with local overturning circulations, a schematic description of which is as follows. The thinning of sea-ice in shelf areas due to katabatic winds is associated with an important ocean heat loss. Brine rejection comes with the formation of new sea-ice. Surface waters get denser, sink to the bottom of the shelf, creating the High Salinity Shelf Waters (HSSW), which then flow toward the open ocean. This export of dense water at depth is balanced by an inflow of surface waters in polynyas, closing the local overturning circulation on the shelf. However, the model study of Marsland et al. (2004) and the observation based study of Williams et al. (2008) show that it can be different and more complex for a single polynya. Both studies highlight an incursion of water in mid depth with outflows at deep and surface in the Mertz Glacier Polynya and the Adelie depression.

The model circulation, when averaged over all polynyas around Antarctica, is very consistent with the schematic description. The structure of this overturning (Fig. 13) is the same in the two simulations: the limit between inflow and outflow is rather steady at $200 \mathrm{~m}$ depth, and its amplitude presents a marked seasonality. The overturning is strong for a period of several months in winter (June-October). The increased activity of polynyas in simulation KATA causes a $2 \mathrm{~Sv}$ increase of the local overturning circulation (Fig. 13), which main amplitude varies from $4 \mathrm{~Sv}$ to $6 \mathrm{~Sv}$ (2-4 Sv in DFS3). The total volume of dense water exported out of polynyas around the whole Antarctica over a year is $4.67 \mathrm{~Sv}$ with the wind correction, an increase of $1.78 \mathrm{~Sv}$ compared to the case without the correction (2.89 Sv, Table 1$)$.
The overturning is associated with a mixing between the relatively warm and salty waters (fed by Circumpolar Deep Waters) underlying the fresher and colder surface waters. The stronger overturning in KATA produces warmer upper ocean temperature (SST is increased by $0.01{ }^{\circ} \mathrm{C}$ in average over all polynyas areas (Table 1), and often $0.05{ }^{\circ} \mathrm{C}$ at the coast, no figure shown) and greater surface salinities (by 0.05 in average over all polynyas areas, see Table 1). Because salinity controls density in cold waters, these changes lead to an increase of surface density $\left(0.04 \mathrm{~kg} \mathrm{~m}^{-3}\right.$ in average over all polynyas areas, see Table 1 ) over a period from April to September. This increase of surface temperature, salinity and density is clearly shown in the T, S diagrams presented in Fig. 14 (for the region of the Cape Darnley Polynya indicated in Fig. 10). This diagram also shows the salinity and temperature increase of the deepest waters (temperature between -1.6 and $0{ }^{\circ} \mathrm{C}$ ).

Changes in surface temperature remain small, both because the SST is strongly constrained around the freezing point. However, heat fluxes are impacted by the correction. As a consequence of the mixing in polynya, a strong cooling occurs below $400 \mathrm{~m}$ after June in the KATA simulation (solid orange line in Fig. 13). Similar cooling occurs in DFS3 but only in September (dashed orange line in Fig. 13). Therefore, in addition of producing denser shelf waters, the katabatic wind correction increases by 3 months the length of the season when polynyas produce and export dense waters.

\subsection{On the continental slope}

Shelf waters produced in polynyas are cold and relatively salty. These waters spread on the shelf until they reach the shelf break, then sink in the deep ocean.

The circulation on the shelf break is illustrated in Fig. 15 which shows an off-shore vertical section of the along shore velocity at 

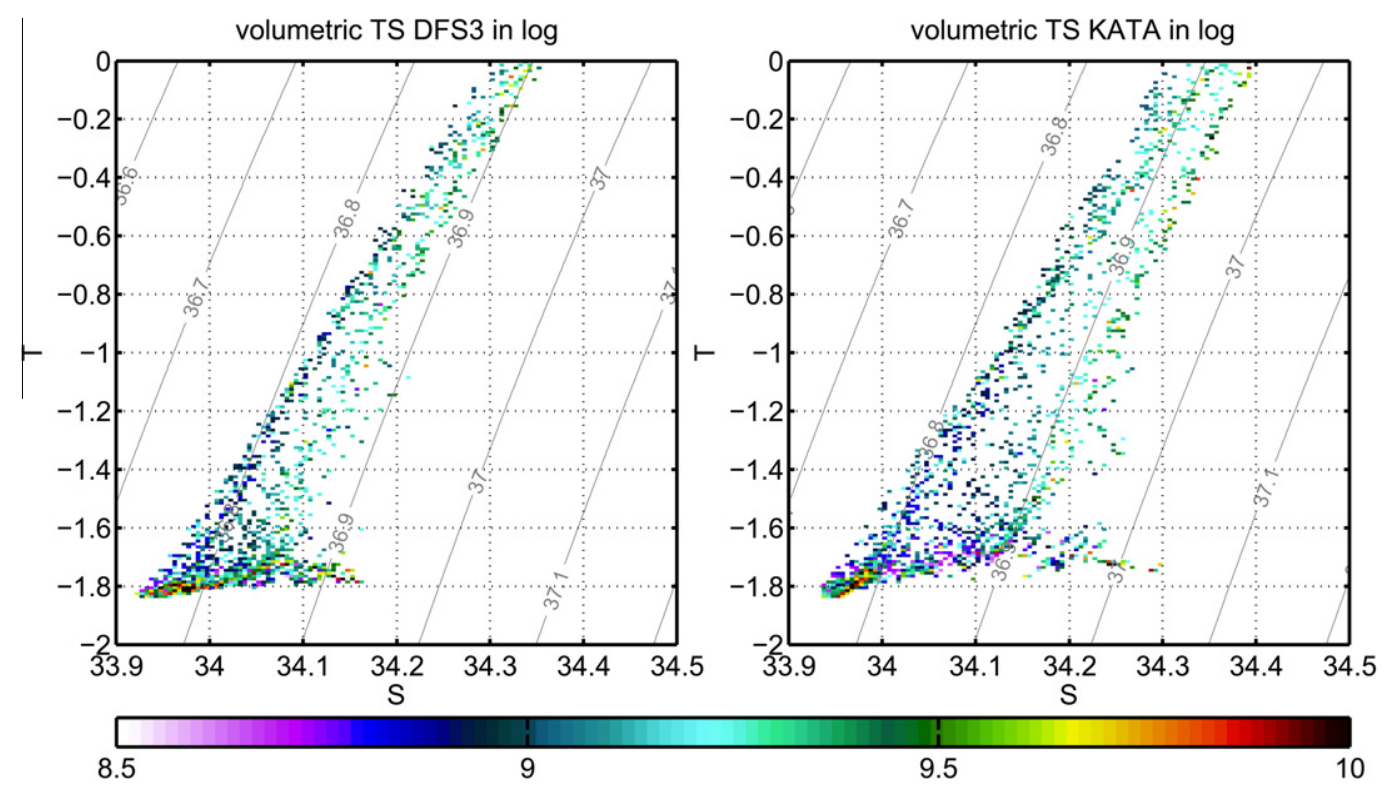

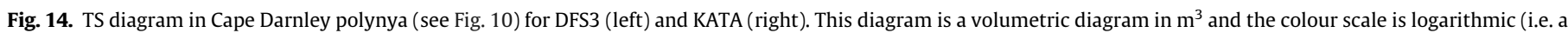
value of 9 indicates a volume of $10^{9} \mathrm{~m}^{3}$ ). $\sigma_{2}$ density contours are shown as grey lines.

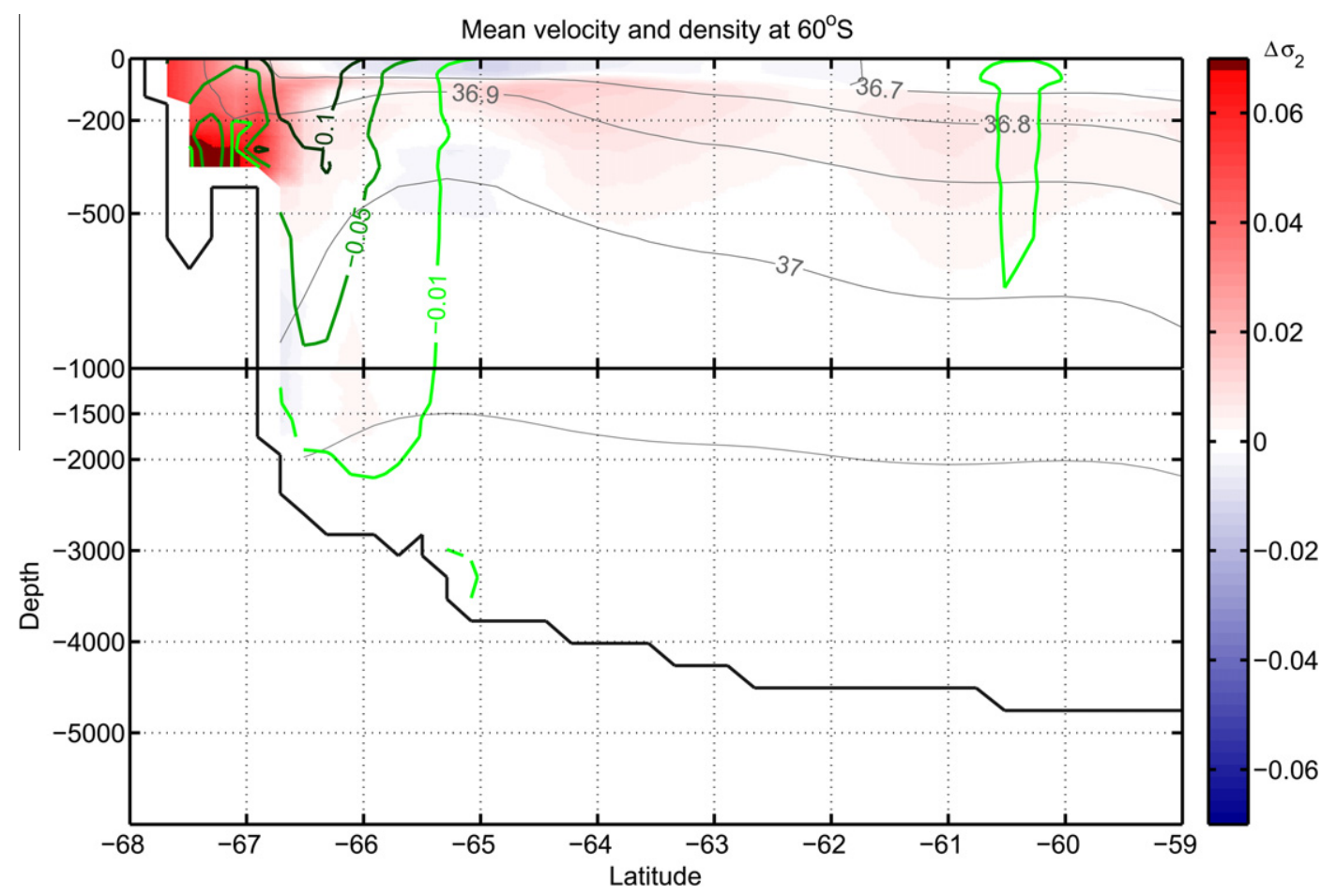

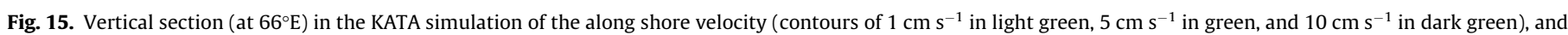

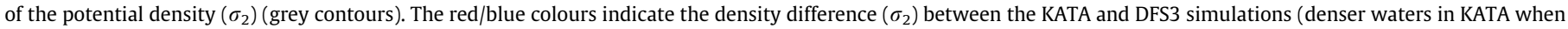
positive). (For interpretation of the references to colour in this figure legend, the reader is referred to the web version of this article.)

$66^{\circ} \mathrm{E}$ (see Fig. 10 for the exact location of the section). This section is exemplary of many other sections around Antarctica.

The anticlockwise (westward) Antarctic Coastal Current (ACoC) appears as a jet locked on the continental slope. The vertical extent of the current reaches $2000 \mathrm{~m}$, and the vertical shear is important, the current velocity being $10 \mathrm{~cm} \mathrm{~s}^{-1}$ at $200 \mathrm{~m}, 5 \mathrm{~cm} \mathrm{~s}^{-1}$ at $500 \mathrm{~m}$, and $1 \mathrm{~cm} \mathrm{~s}^{-1}$ at $2000 \mathrm{~m}$. On the shelf, the shelf waters produced in polynyas (waters denser than $\sigma_{2}=36.9 \mathrm{~kg} \mathrm{~m}^{-3}$ ) spread from the surface to the bottom of the shelf, and connect and mix with the waters of the slope. As previously discussed, the katabatic wind correction increases the density of the waters on the shelf, but especially at the bottom (by an amount of $\Delta \sigma^{2}=0.07 \mathrm{~kg} \mathrm{~m}^{-3}$ as illustrated by the density difference shown by the colours scale in Fig. 15). Unfortunately, shelf waters rapidly mix with the water of the slope rather than sinking to greater depth to feed the AABW, a typical flaw of $z$-coordinate models (Griffies et al., 2000).

The impact of the katabatic correction on the ACoC is shown in Fig. 16, which displays for both KATA and DFS3 simulations, the mean (1990-2000) seasonal cycle of the ACoC transport, integrated from surface to bottom, across a number of sections around 

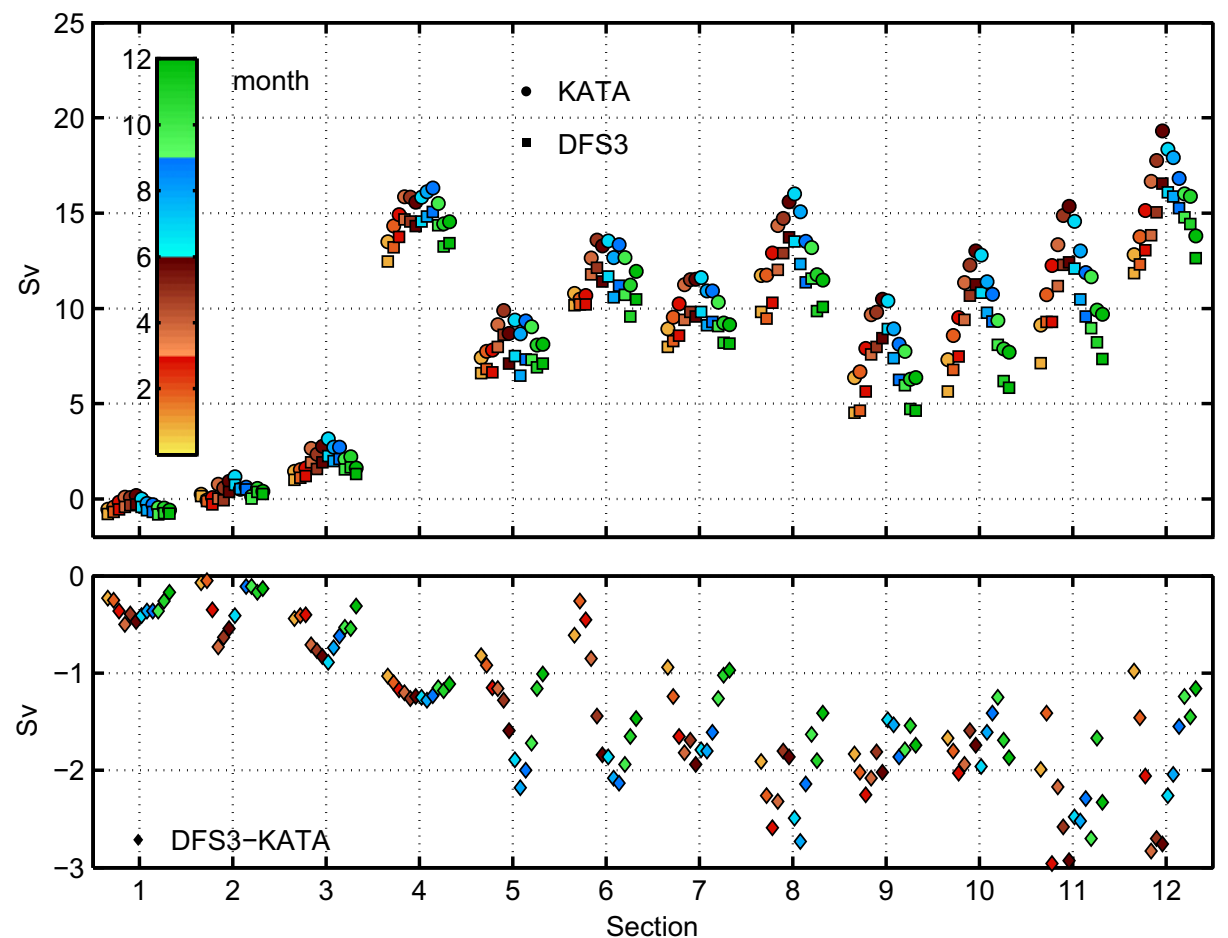

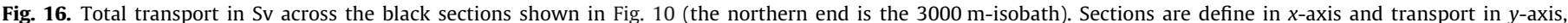

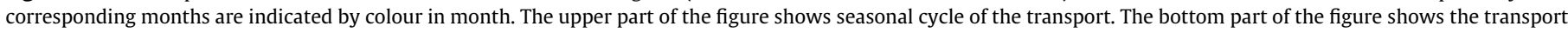
difference between KATA and DFS3. Negative anomaly means stronger ACoC in KATA

Antarctica (see Fig. 10 for the location and numbering of the sections, the northern end of the section being the $3000 \mathrm{~m}$ bathymeter line).

The timing of the seasonal cycle is similar in both simulations (as expected since the seasonal cycle of the forcing is the same). Maximum transport occurs in June and July for all sections. However, the mean transport and the amplitude of the seasonal cycle greatly vary from one section to another, but this variation is very consistent and robust between the simulations. The transport of the ACoC increases as it flows westward around the Antarctic Peninsula. On the west side of the Antarctic Peninsula (Section 1) the transport is always nearly zero and even changes sign (eastward flow) with the season. Peak values in transport (over $15 \mathrm{~Sv}$ ) are noticed at the exit of the Ross Sea Gyre (Section 4) and at the exit of the Weddell Sea Gyre (Section 12).

These two extreme values are due to the fact that the $\mathrm{ACoC}$ includes part of the gyres' recirculation at these locations. Therefore, the katabatic wind correction has no impact on the circumpolar pattern of the $\mathrm{ACoC}$ which remains the same in both simulations. Thus, the impact of the wind correction appears to be limited to the amplitude of the flow, the ACoC transport being systematically stronger (by 1-3 Sv) in KATA (Fig. 16, bottom plot). Note that the difference in transport between the two simulations also exhibits a marked seasonal cycle. This increase in transport in KATA is related to the local wind effect. Consistent with the process described by Bindoff et al. (2000), the increase of the along shore component of the wind stress induced by the correction pushes surface waters inshore. This increases the off-shore pressure gradient, and in turn increases the strength of the ACoC.

\section{Conclusion}

A correction of ERA40 wind velocity around the coast of Antarctica that accounts for the underestimation of the katabatic winds in ERA40 has been constructed. The correction is based on a compar- ison over the period 1980-1989 of ERA40 reanalysis wind stress and the wind stress obtained by a downscaling of ERA40 by the MAR regional atmospheric model. The correction takes the form of a constant in time but spatially varying multiplying factor (ranging, for the stress, from 6 to slightly less than 1, its square root is used for the wind velocity). Its application is limited to very near-coast regions around Antarctica corresponding to the patches of maximum difference between ERA40 and MAR. It is applied to ERA40 wind velocity vector over the whole reanalysis period from 1958 to 2001.

The impact of this correction on sea-ice and hydrography around Antarctica is assessed from twin simulations (with the correction, simulation referred to as KATA, and without, simulation referred to as DFS3) performed over the period 1958-2001 with the medium resolution ( $\sim 20 \mathrm{~km}$ around Antarctica) global ocean/ sea-ice model configuration ORCA05 (based on the NEMO numerical code). The correction, which is applied to the wind velocity, does impact all turbulent fluxes driving the model (wind stress, evaporation, sensible and latent heat fluxes), through the use of bulk formulas. Because it is local, the correction is expected to have its greatest impact on coastal polynyas and coastal waters. Coastal polynyas are defined as areas where ice production is greater than $0.7 \mathrm{~m}$ per month and where the ocean depth is less than $1200 \mathrm{~m}$.

The katabatic correction globally induces a $115 \%$ increase of the wind stress in polynya areas, which consequently increases the activity of coastal polynyas. These features represent a greater area $(+24 \%)$, and produce significantly more sea-ice $(+42 \%)$ compared to the simulation with the standard ERA40 winds (DFS3). The characteristics of coastal polynyas (1-1.5\% of total ice area and $10-15 \%$ of total ice production) are consistent with other estimates from models or observations. This increased activity of polynyas in simulation KATA causes an increase of the vertical mixing and an increase of the local overturning circulation $(+2 \mathrm{~Sv})$. This overturning increase in KATA corresponds to a greater export from polynyas of colder and denser water than in DFS3. This water spreads to the shelf break but still is not dense enough to realisti- 
cally feed the AABW. Even with realistic formation of shelf water, an improvement of bottom boundary layer parameterisation used in NEMO is fundamental to produce realistic AABW.

The presence of a zonal wind stress along the coast allows the presence of an anticlockwise current along the slope and Antarctica shelf. This study has also pointed out the large seasonal cycle of the ACoC, still a not well-observed feature, and the heterogeneity of its circumpolar structure. The increase of the zonal wind velocity in KATA increases the amplitude of the ACoC between +1 and $+3 \mathrm{~Sv}$, depending on the season), but does not impact its circumpolar pattern. Improvements brought by the katabatic wind correction are thus noticeable.

The next step of this study would be to use all forcing variables (i.e. air temperature, air humidity, radiation, etc.) produced by the MAR downscaling beyond a given latitude, as made by Mathiot et al. (submitted for publication) for a regional model of the Ross Sea. This later study showed that the air temperature produced by MAR was significantly colder in summer than the one of ERA40, which could contribute to correct the insufficient sea-ice cover in summer.

\section{Acknowledgements}

The authors acknowledge support from Ministère de l'Education Nationale et de la Recherche and from Centre National de la Recherche Scientifique (CNRS). This work is a contribution of the DRAKKAR project. Support to DRAKKAR comes from various grants and programs listed hereafter: French national programs GMMC, LEFE, and PICS2475. The contribution of Institut National des Sciences de l'Univers (INSU) to these programmes is particularly acknowledged. DRAKKAR acknowledge the support from the Centre National d'Etudes Spatiales (CNES) through the OST/ST. Computations presented in this study were performed at Institut du Développement et des Ressources en Informatique Scientifique (IDRIS). Partial support from the European Commission under Contract SIP3-CT-2003-502885 (MERSEA project) is gratefully acknowledged. The authors are also grateful to the members of the DRAKKAR group for their lively discussions and comments during the annual DRAKKAR meeting. Josiane Brasseur is thanked for her continuous support. The authors acknowledge the very constructive and precise comments of two anonymous reviewers.

\section{References}

Adolphs, U., Wendler, G., 1995. A pilot study on the interactions between katabatic winds and polynyas at the Adelie Coast, Eastern Antarctica. Antarctic Sci. 7, 307-314.

Baines, P.G., Condie, S., 1998. Observations and modelling of Antarctic downslope flows: a review. Antarctic Res. Ser. 75, 29-49.

Barnier, B., Madec, G., Penduff, T., Molines, J.-M., Treguier, A.-M., Le Sommer, J., Beckmann, A., Biastoch, A., Böning, C., Dengg, J., Derval, C., Durand, E., Gulev, S., Remy, E., Talandier, C., Theeten, S., Maltrud, M., McClean, J., De Cuevas, B., 2006. Impact of partial steps and momentum advection schemes in a global ocean circulation model at eddy-permitting resolution. Ocean Dynam. 56, 543-567.

Beckmann, A., Doesher, R., 1997. A method for improved representation of dense water spreading over topography in geopotential-coordinate models. J. Phys. Oceanogr. 27, 581-591.

Biastoch, A., Böning, C., Getzlaff, J., Molines, J.-M., Madec, G., 2008a. Causes of interannual - decadal variability in the meridional overturning circulation of the mid-latitude North Atlantic Ocean. J. Clim. 21, 6599-6615. doi:10.1175/ 2008JCLI2404.1.

Biastoch, A., Böning, C., Lutjeharms, J.R.E., 2008b. Agulhas leakage dynamics affects decadal variability in Atlantic overturning circulation. Nature 456, 489-492. doi: $10.1038 /$ nature 07426

Bindoff, N.L., Rosenberg, M.A., Warner, M.J., 2000. On the circulation and water masses over the Antarctic continental slope and rise between 80 and $150 \mathrm{E}$. Deep Sea Res. II 47, 2299-2326.

Brodeau, L., Barnier, B., Penduff, T., Treguier, A.-M., Gulev, S., 2010. An ERA40 based atmospheric forcing for global ocean circulation models. Ocean Modell. 31, 88104.

Bromwich, D.H., Kurtz, D.D., 1984. Katabatic wind forcing of the terra Nova Bay Polynya. J. Geophys. Res. 89, 3561-3572.
Cavalieri, D. J., Parkinson, C.I., Gloersen, P., Zwally, H.J., 1997. Arctic and Antarctic Sea-Ice Concentrations from Multichannel Passive-microwave Satellite Data Sets: October 1978-December 1996, User's Guide. NASA Technical Memorandum 104647.

Cunningham, S., Alderson, S., King, B., Brandon, M., 2003. Transport and variability of the Antarctic circumpolar current in Drake Passage. J. Geophys. Res., 108 C05.

Davis, A.M.J., Mc Nider, R.T., 1997. The development of Antarctic katabatic winds and implications for the Coastal Ocean. J. Atmos. Sci. 54, 1248-1261.

DRAKKAR-Group, 2007. Eddy permitting ocean circulation hindcast of past decades. CLIVAR Exchanges Lett. 12, 8-10.

Duynkerke, P., 1988. Application of the e-turbulence closure model to neutral and stable atmospheric boundary layer. J. Atmos. Sci. 45, 865-880.

Fetterer, F., Knowles, K., 2004. Sea-ice index monitors polar ice extent. Eos Trans. AGU, 16.

Fichefet, T., Morales Maqueda, M.A., 1997. Sensitivity of a global sea-ice model to the treatment of ice thermodynamics and dynamics. J. Geophys. Res. 102, 12609-12646.

Gallée, H., Schayes, G., 1992. Dynamical aspects of katabatic winds evolution in the antarctic coastal zone. Boundary Layer Meteorol. 59, 141-161.

Gallée, H., Schayes, G., 1994. Development of a three dimensional meso-scale primitive equations model, katabatic winds simulation in the area of Terra Nova Bay. Antartic Mon. Weather Rev. 122, 671-685.

Gill, A.E., 1973. Circulation and bottom water production in the weddell sea. Deep Sea Res. 20, 111-140.

Griffies, S.M., Böning, C., Bryan, F.O., Chassignet, E.P., Gerdes, R., Hasumi, H., Hirst, A. Treguier, A.-M., Webb, D., 2000. Developments in ocean climate modeling. Ocean Modell. 2, 123-192.

Ingleby, B., Huddleston, M., 2007. Quality control of ocean temperature and salinity profiles - historical and real-time data. J. Mar. Syst. 65, 158-175. doi:10.1016 j.jmarsys.2005.11.019.

Jourdain, N.C., Gallée, H., 2010. Influence of the orographic roughness of glacier valleys across the Transantarctic Mountains in an atmospheric regional model Clim. Dynam., in press, doi:10.1007/s00382-010-0757-7.

Juza, M., Penduff, T., Brankart, J.-M., Barnier, B., submitted for publication. Estimating the distortion of mixed layer property distributions induced by the ARGO sampling. J. Geophys. Res.

Kim, S.J., Stossel, A., 1998. On the representation of the Southern Ocean water masses in an ocean climate model. J. Geophys. Res. 103 (C11), $24891-$ 24906.

Lachkar, Z., Orr, J.C., Dutay, J.-C., Delecluse, P., 2007. Effects of mesoscale eddies on global ocean distributions of CFC-11, CO2, and 14C. Ocean Sci. 3, 461-482.

Large, W.G., Yeager, S.G., 2004. Diurnal to Decadal Global Forcing for Ocean and Seaice Models: The Data Sets and Flux Climatologies. Technical Report TN460+STR, NCAR, 105pp.

Madec, G., 2008. The NEMO Ocean Engine. Note du Pôle de Modlisation de L'IPSL <http://www.nemo-ocean.eu/About-NEMO/Reference-manuals>.

Maqueda, M.A., Willmot, A.J., Biggs, N.R.T., 2004. Polynya dynamics: a review of observations and modelling. Rev. Geophys., 42.

Marsland, S.J., Bindoff, N.L., Williams, G.D., Budd, W.F., 2004. Modeling water mass formation in mertz glacier polynya and adélie depression, east Antarctica. J. Geophys. Res. 109 (C11).

Massom, R., Harris, P.T., Michael, K.J., Potter, M.J., 1998. The distribution and formative processes of latent heat polynyas in East Antarctica. Ann. Glaciol. 27 420-426.

Mathiot, P., 2009. Influence du forage atmosphérique sur la représentation de la glace de mer et des eaux de plateau en Antarctique dans une étude de modélisation numérique, Ph.D. Thesis. Université Joseph Fourier. <http:// www.tel.archives-ouvertes.fr/tel-00375960>.

Mathiot, P., Jourdain, N.C., Barnier, B., Gallée, H., Molines, J.M., Le Sommer, J., Penduff, T., submitted for publication. Sensitivity of a model of Ross Sea polynyas to different atmospheric forcing sets. Ocean Dynam.

Parish, T.R., 1988. Surface winds over the Antarctic continent: a review. Rev. Geophys. 26, 169-180.

Petrelli, P., Bindoff, N.L., Bergamasco, A., 2008. The sea-ice dynamics of Terra Nova Bayand Ross Ice Shelf Polynyas during a spring and winter simulation. J Geophys. Res. 113 (C09).

Roeske, F., 2005. A global heat and freshwater forcing dataset for ocean models. Ocean Modell. 11, 235-297.

Simmons, A.J., Gibson, J.K., 2000. The era-40 Project Plan. Technical Report, ERA-40 Project Report Series.

Tamura, T., Ohshima, K.I., Nihashi, S., 2008. Mapping of sea-ice production for Antarctic coastal polynyas. Geophys. Res. Lett. 12 (L07).

Timmermann, R., Worby, A., Goosse, H., Fichefet, T., 2004. Utilizing the ASPeCt seaice thickness data set to evaluate a global coupled sea-ice-ocean model. J. Geophys. Res. 109 (C07).

Uppala, S. et al., 2005. The ERA40 reanalysis. Quart. J. Roy. Meteorol. Soc. 131, 2962 3012.

Van Den Broeke, M.R., Van Den Wal, R.S.W., Wild, M., 1997. Representation of Antarctic katabatic winds in a hight resolution CM and a note on their climate sensitivity. J. Clim. 10, 3111-3130.

Williams, G.D., Bindoff, N.L., Marsland, S.J., Rintoul, S.R., 2008. Formation and export of dense shelf water from the Adélie depression, East Antarctica. J. Geophys. Res. 113 (C04).

Worby, A., Geiger, C., Paget, M., Woert, M.V., Ackley, S., DeLiberty, T., 2008. The thickness distribution of Antarctic sea-ice. J. Geophys. Res. 113 (C05). 